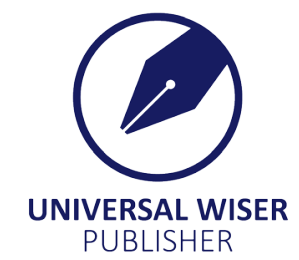

\title{
Nanotechnology Utilization in Energy Conversion, Storage and Efficiency: a Perspective Review
}

\author{
Abdalla M. Abdalla ${ }^{1, *}$, Bassem E. Elnaghi ${ }^{2}$, Shahzad Hossain ${ }^{3}$, Mohamed Dawood ${ }^{1}$, O. Abdelrehim ${ }^{4}$, Abul $^{\circ}$ \\ K. Azad $^{5}$ \\ ${ }^{1}$ Mechanical Engineering Department, Faculty of Engineering, Suez Canal University, Ismailia 41522, Egypt \\ ${ }^{2}$ Electrical Engineering Department, Faculty of Engineering, Suez Canal University, Ismailia 41522, Egypt \\ ${ }^{3}$ Institute of Nuclear Science and Technology, Bangladesh Atomic Energy Commission, GPO Box No 3787, Dhaka 1000, Bangladesh \\ ${ }^{4}$ Mechanical Power Engineering Department, Faculty of Engineering, Mansoura University, El-Mansoura, 35516, Egypt \\ ${ }^{5}$ Faculty of Integrated Technologies, Universiti Brunei Darussalam, JalanTungku Link, Gadong BE 1410, Brunei Darussalam \\ Email: abdalla.m.a1984@eng.suez.edu.eg
}

\begin{abstract}
World needs have revolved around the use of nanotechnology in most vital applications especially in the energy sector. From which has a major role in the application of this technology in several aspects as the conversion of energy, the storage of energy and efficiency of energy. Through the ongoing research by scientists and researchers to incorporate nanotechnology as one of the essential technologies at present and in the future, which has shown the strength of nanotechnology in reaching the possible superior efficiency. In this review, we present various important applications of nanotechnology involved in the three main directions (energy conversion, energy storage and energy efficiency). These ultimate goals of the nanotechnology utilization in the energy sector will offer the high demand of energy efficiency with minimum losses and high durability in the clean and sustainable resources.
\end{abstract}

Keywords: nanotechnology, energy conversion, energy storage, energy efficiency

\section{Introduction}

Nanotechnology progress and fast growing in a particular energy field ${ }^{[1-6]}$ and its utilization in portable and smart devices ${ }^{[2]}$ has gained the whole attention today. Thereby, presenting a durable, flexible, and long lifespan ${ }^{[7]}$ of this technology in energy (storage, conversion, and efficiency) is essentially desired. Various applications in the energy field like thermal, magnetic, electric, kinetic, acoustic and optical are in deep requirement to enhance the performance within a minimized scale (Nano-level) ${ }^{[1]}$. Moreover, current research work using different energy conversion methods (thermal, thermochemical, biochemical, chemical, electrochemical, mechanical, nuclear and gravitational) are able to convey the maximum power ${ }^{[8-11]}$. Energy management of this power is mainly depends on bridging and distributing storage through the direct and the indirect storage methods ${ }^{[12]}$. Hence, this will be reflected through the efficient energy prior to a variety of needs like lightweight/portable, high energy storage capacity, low manufacturing cost, high performance at low temperatures and faster energy transfer ${ }^{[13,14]}$. In order to guarantee a full balance in the energy triangle which represented by I) Energy storage, II) Energy generation and III) Energy consumption ${ }^{[15]}$, the way of delivering the energy should be improved using the nanotechnology levels ${ }^{[16]}$ compared to the macroscopic levels.

Utilization of nanotechnology in the energy sector has shown a remarkable sign based on advantages that presented in multidisciplinary industries and applications. The rapid growing of nanotechnology in energy was achieved through the fast trend from conventional to Nano-scale level which is mainly subjected to the different types of used materials, including graphite/graphene (carbon based) nanomaterials, nanocrystalline (nanosized thin films and ball milled metals) and nanocomposites (carbon, polymers, metals and ceramics) ${ }^{[1,17,18]}$.

Likewise, in the energy sector ${ }^{[19]}$, nanotechnology role as an essential part in so many energy sources such as hydrogen energy, wind energy, biomass energy, tidal energy equipment, geothermal energy, solar cells, fuel cells and batteries they are pointed out in Figure 1.

Copyright (C)2020 Abdalla M. Abdalla, et al.

DOI: https://doi.org/10.37256/aecm.11202075

This is an open-access article distributed under a CC BY license

(Creative Commons Attribution 4.0 International License)

https://creativecommons.org/licenses/by/4.0/ 


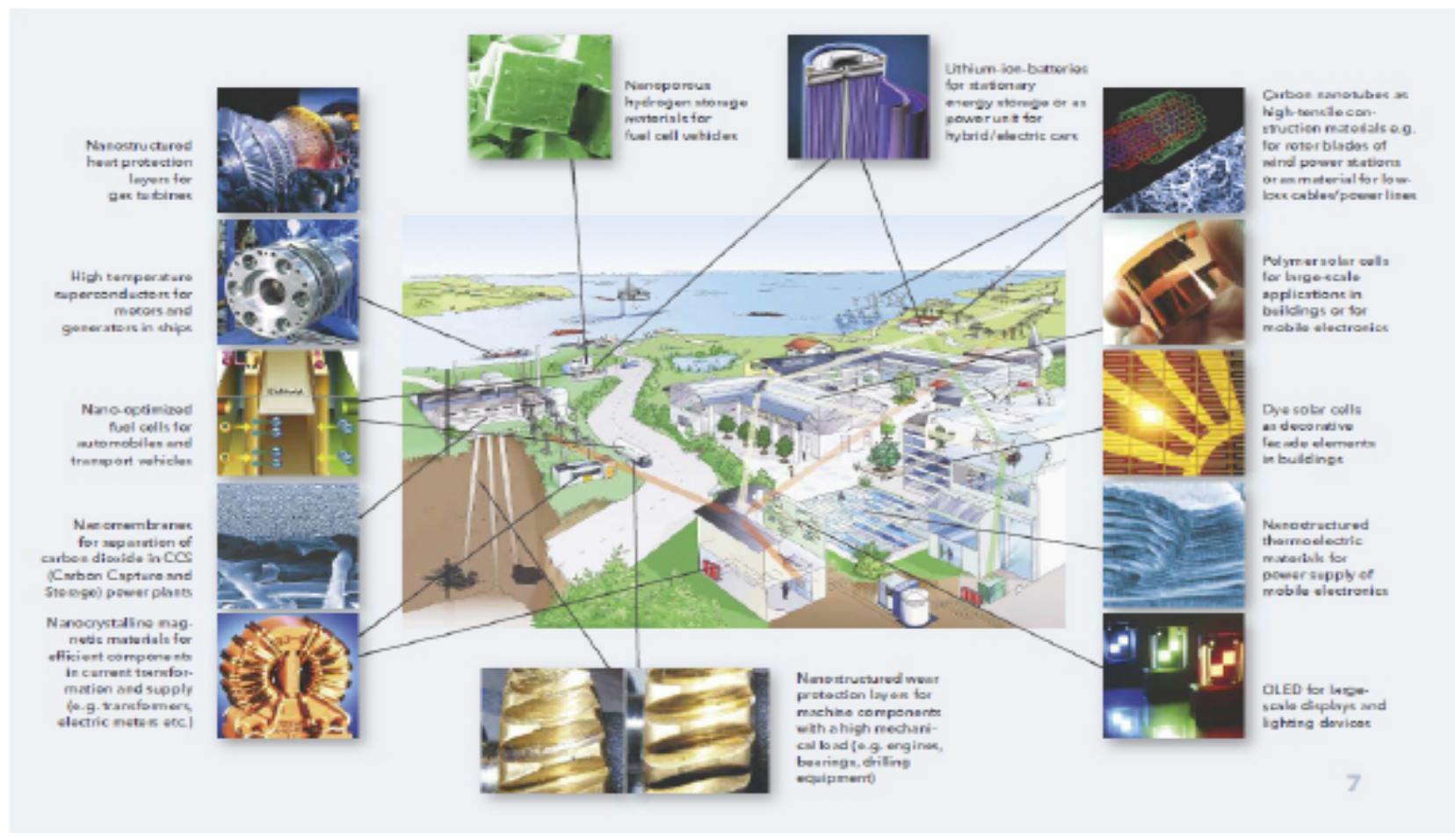

Figure 1. Utilization of nanotechnology and power requirement in different application of energy sector ${ }^{[19]}$

In this paper, we are not trying to present only a perspective review of the most essential applications of nanotechnology, but also focusing on three main aspects of energy field namely energy conversion, storage and efficiency that cover the whole energy sector.

\section{Nanotechnology trends in energy field}

The perception of nanotechnology in the energy sector requires awareness of the general characteristics of fundamental energy carriers through the summery of length and time scales in liquid, gases and solids ${ }^{[20]}$. The enhancement of the energy system performance demands a concise definition of material scales (see Figure 2) within time-span that is mainly affected by the energy carrier transport, conversion and storage processes ${ }^{[20,21]}$.

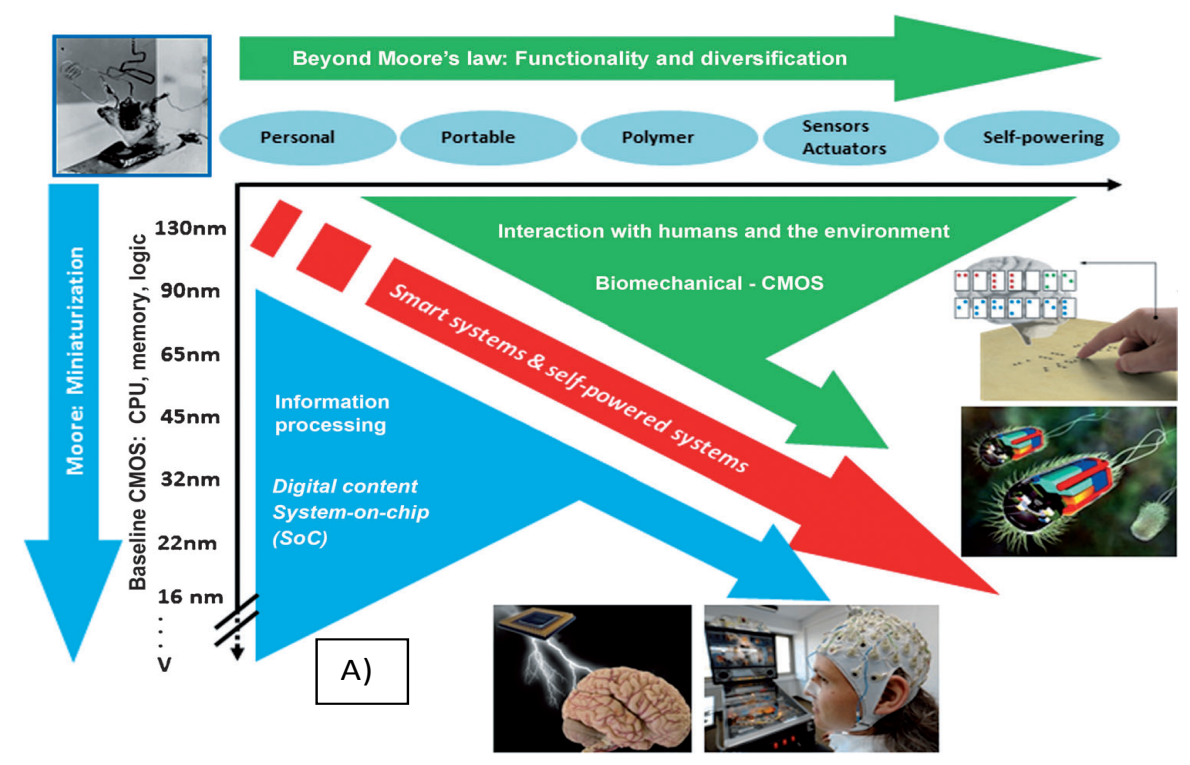




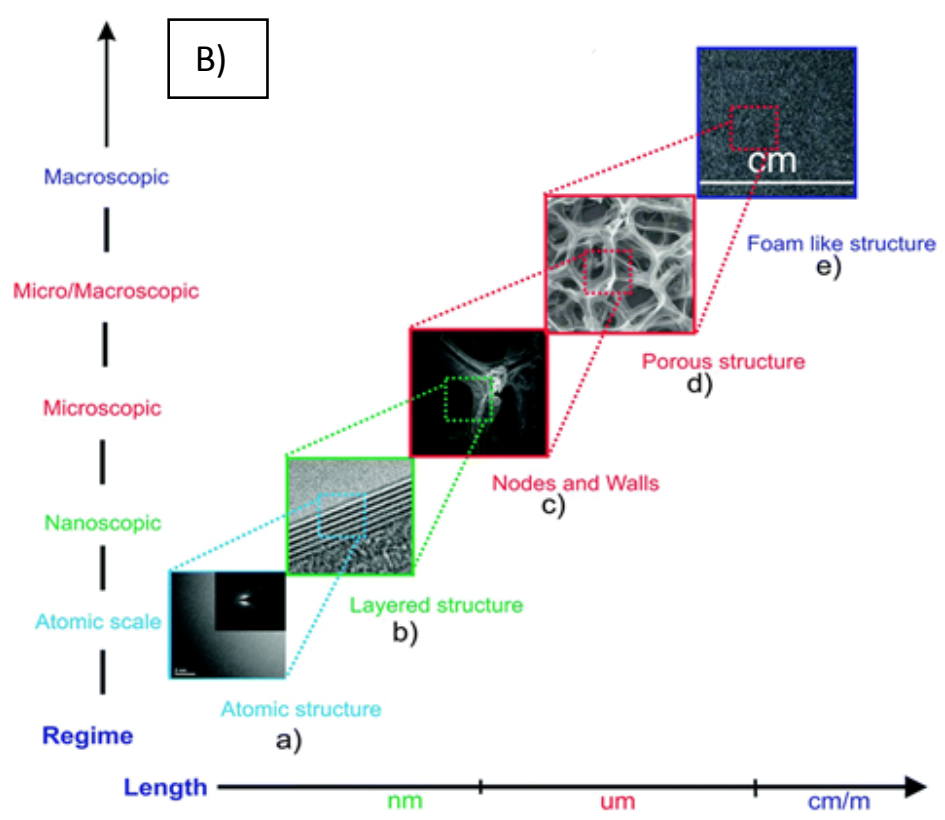

Figure 2. Material scales from macroscopic to atomic structural levels in a) in a real life a applications and b) in real microstructure regime ${ }^{[2,22]}$

Since the recent two decades, nanotechnology has appeared as a powerful tool in energy field with the support of efficient, renewable energy conversion, storage and conservation in providing the whole needs of the energy sector ${ }^{[23]}$. Thereby, this transformative technology enables the overcoming of the limited term resources, insufficient and highly expensive of the present technology and its impact of the environmental effect as well. Basically, There are two main stages in energy processing (conversion and storage) and between these two stages we can control by conservation (see Figure 3) ${ }^{[20]}$. Hence, it is essential to clarify the nanotechnology trends related to these main aspects and how far it is applicable today.

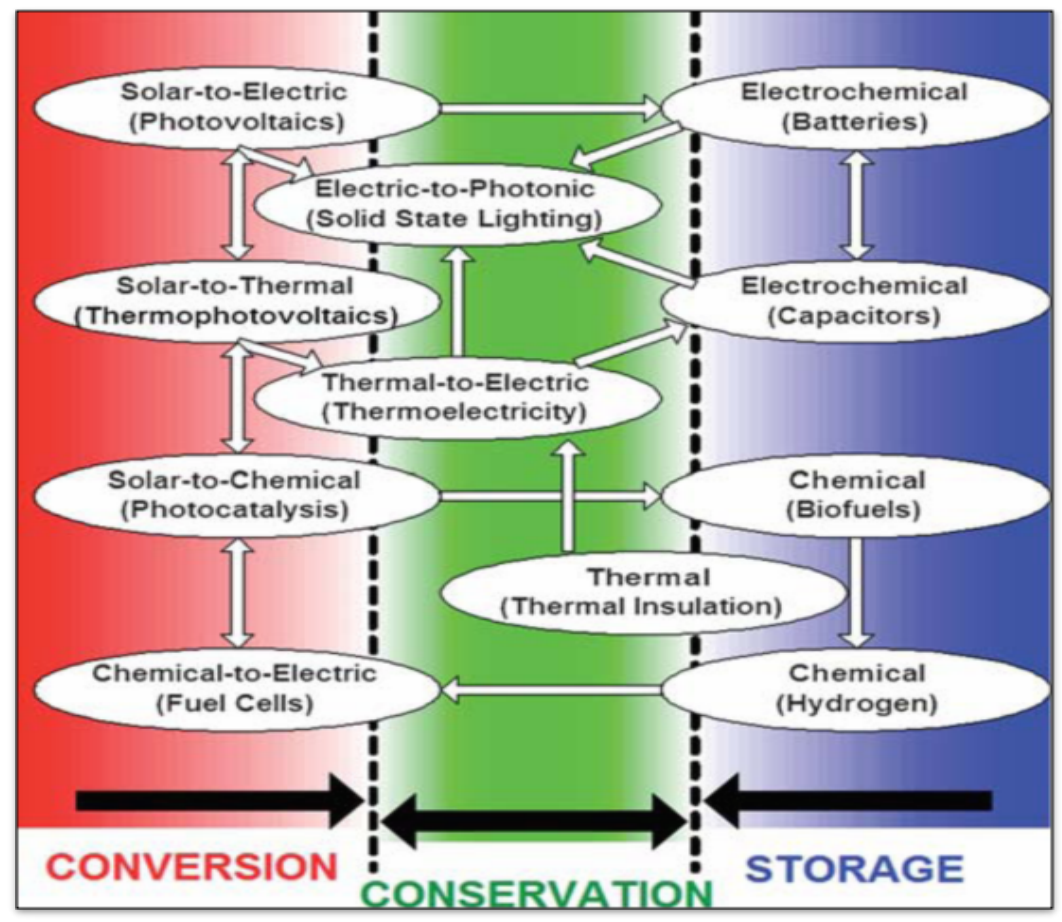

Figure 3. Network of the (technology boxes) energy elements and the coherence of the whole stage together ${ }^{[20]}$ 
Nanotechnology trends can be easily noticed through the research progress and applications in versatile majors ${ }^{\text {[24] }}$ specifically those satisfy our daily needs, for instance energy provisions. However, nanotechnology understanding is mainly based on three aspects a) synthesis and fabrications, b) characterizations and c) performance testing ${ }^{[25]}$, but the feedback reflection of these aspects are essentially impacted the progress of this technology ${ }^{[26]}$ and increases its utilization successively in energy conversion, storage and efficiency.

M. Zach et al. ${ }^{[25]}$ have shown the progress of nanoscience in energy and environment related issues until 2006. There by, in Figures 4 and 5 the research trend of the nanotechnology in the energy sector since 1991 until today is presented and from both figures it is clearly that this technology is extremely increased.

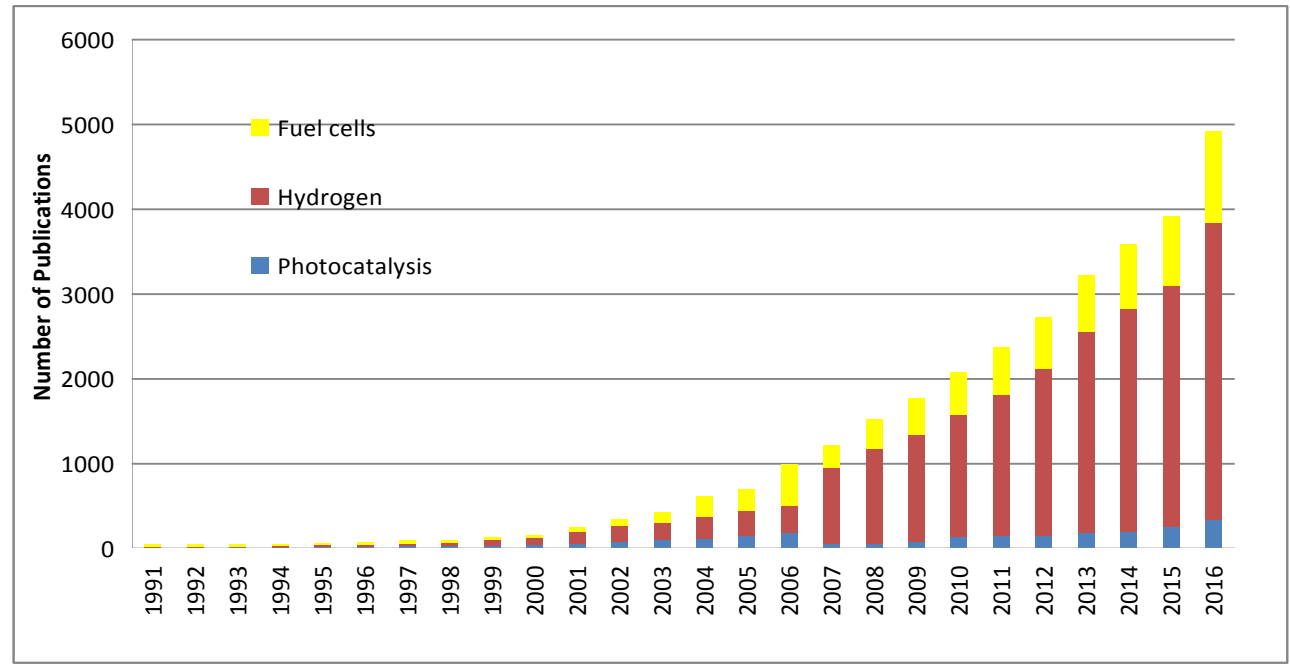

Figure 4. Nano-science and nanotechnology number of publications and research spot in energy sector, according in few selected areas and data were obtained from the ISI web of science ${ }^{[2}$

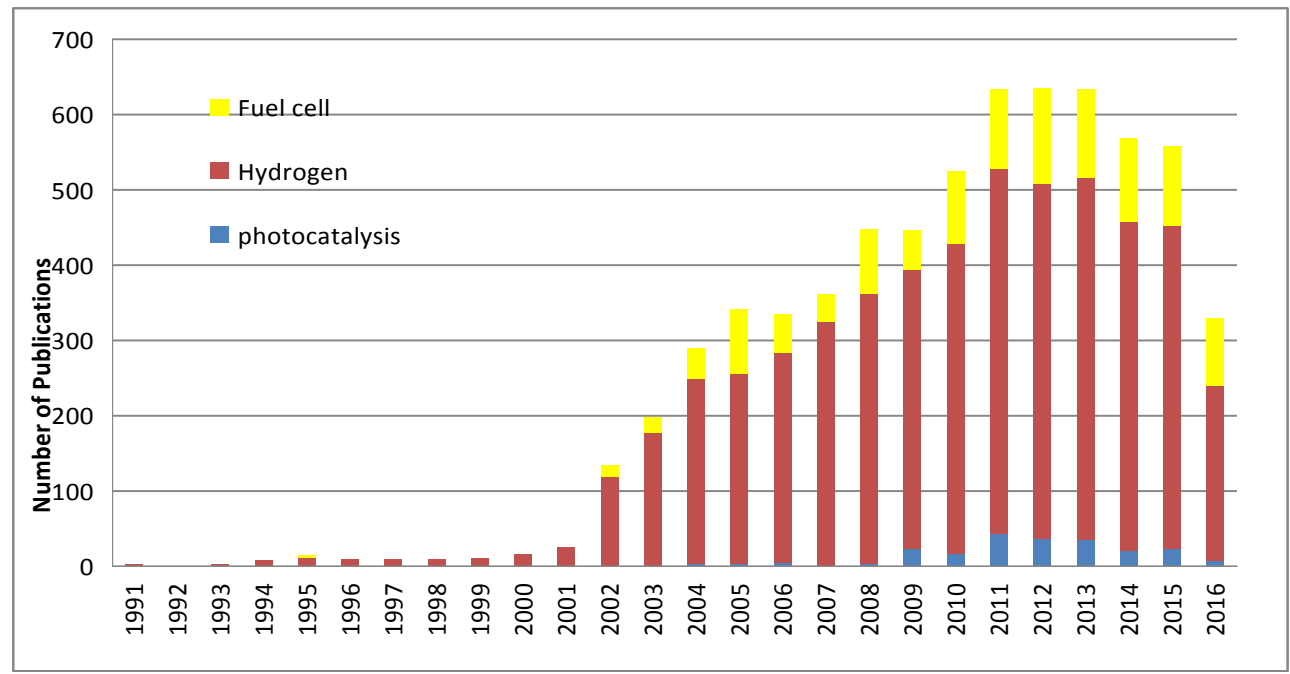

Figure 5. Nano-science and nanotechnology number of publications and research spot in energy sector, according in few selected areas and data were obtained from SCOPUS web of science

\section{Recent nanotechnological initiative in energy sector}

Based on what have been stated previously, the coming topics will cover the utilization of nanotechnology of different energy related application areas through conversion, storage and efficiency as observed in Figure 6. 


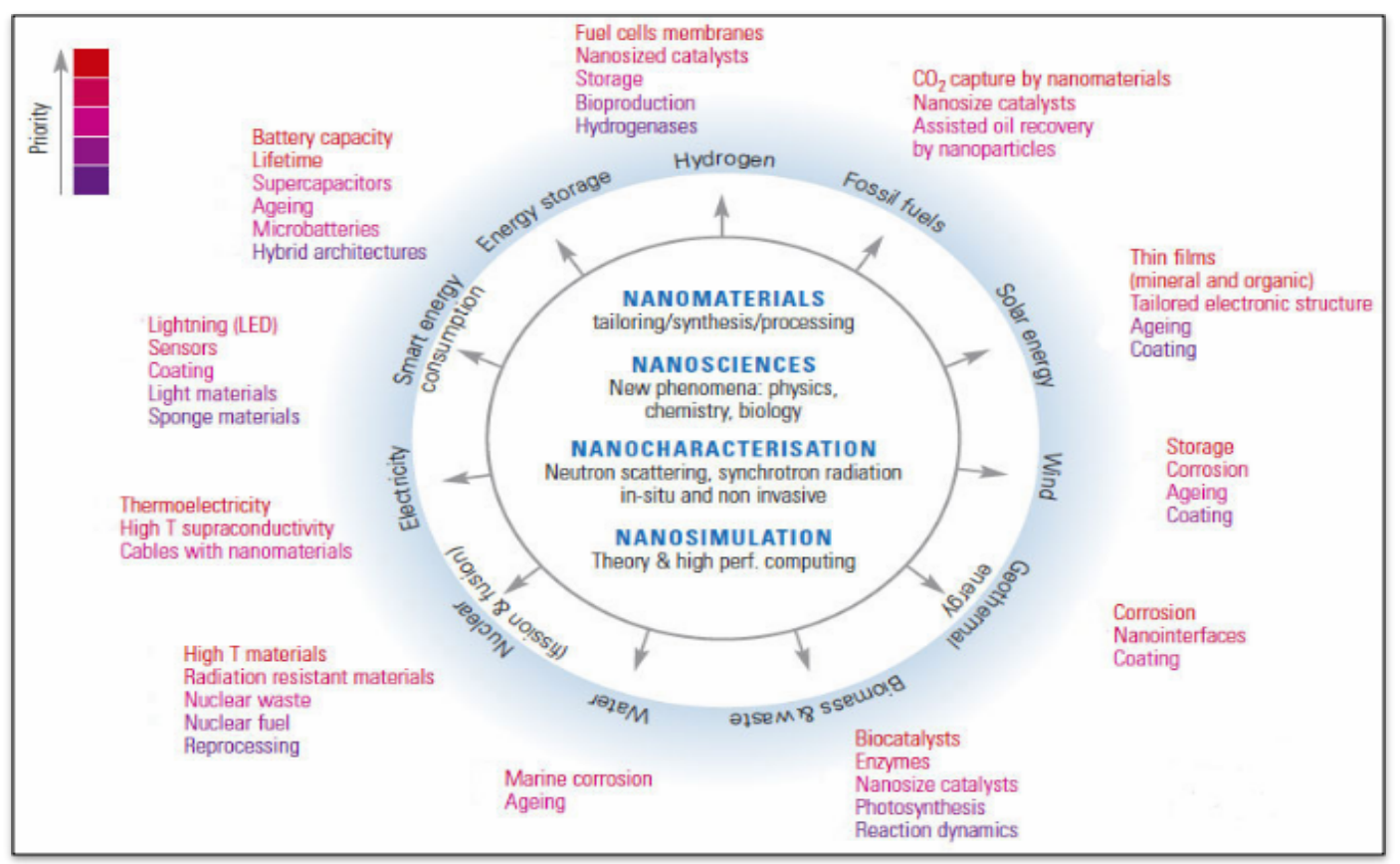

Figure 6. An overview of Nano-science in the energy related applications ${ }^{[28]}$

Nanotechnology tends to be the method of using the nanoscience discoveries in various sensitive applications. For instance, some nanostructured materials are well assembled and self-ordered. Thereby, a possibility of materials atom design can be achieved for particular and crucial applications. This recommends the nanotechnology as a highly potential and efficient in various energy sectors. Moreover, some recent initiatives of nanotechnology in the energy sector can be easily summarized and considered because of the promising future with the massive development and applications potential in many energy fields. Therefore, the main initiative topics can be drawn from the following points:

(i) Essentially and strategically important focus for energy research and industrial applications.

(ii) Strengthening research competence in a related energy fields with various applications in multi sectors like convergence, storage and efficiency.

(iii) Speed up technology relocate and rising the economic exploitation of nanotechnology

(iv) Guarantee the continuous collaboration with international partners and overcome the common threats that face the technical and scientific issues.

(v) Give more attention to health risks and environmental hazardous with high level of security and control.

(vi) Provide a nanotechnology database system that helps scientists and researchers to collect all needed information in their investigations especially in different energy sectors.

\section{Applications in energy conversion}

The process of converting energy through multiple sources is the key to the tremendous development we are witnessing these days ${ }^{[29]}$, which are manifested through several levels and scales. The importance of nanotechnology comes from how it includes and permeates all applications, especially that provide more efficient, higher flexibility and less expensive energy. So, to promote this technology as a promising and leading direction today and in the future, this section will focus on the applications of the nanotechnology utilizations in the most important energy conversion applications.

\subsection{Solar energy}

The solar energy was discovered by Frank Shuman ${ }^{[30]}$ who presented his first contribution to the world between 1912 and 1913 by building a solar thermal power station in Maadi, Egypt. Despite the promising outcomes Shuman got at the time, the oil discovery in 1930 shrank the advancement of solar energy and the fossil fuel got more attention regardless the benefits that solar energy can offer as a renewable source of energy. Meanwhile, the world has faced challenges with the usage of fossil fuels like run out problems ${ }^{[30,31]}$ and the environmental issues ${ }^{[32]}$. Thus, it was very urgent and well desired to adopt clean and sustainable resources which have stated specifically on $1970{ }^{[30]}$. Intensive work has been considered 
by scientists to convert the solar energy into the electricity ${ }^{[33,34]}$ and their target was to handle out the solar energy and to optimize this power into every usable device and equipment needed for any human activity. The revolutionary nanotechnology is used to improve the performance of different solar energy fields as shown in Table $1^{[35-41]}$. The use of nanotechnology in solar panels can be briefly described through the enhancement of the various dopant elements properties from nanostructure cell arrangements, sub- lattice and extend optical absorption into the visible region. Three-dimensional schematic representation of atom in the cell Figure 7. Meanwhile, higher efficiency can be concurrent by nanotechnology and its impact on the solar sector presented Figure 8.

Table 1. Some selected applications of nanotechnology in solar cell

\begin{tabular}{|c|c|c|}
\hline Application & Results and findings & Ref \\
\hline Solar collector & $\begin{array}{l}\text { The nanofluid based solar collector had a lower embodied energy (about 9\%) and approximately (3\%) higher } \\
\qquad \text { levels of pollution off sets than a conventional collector. }\end{array}$ & [43] \\
\hline Solar collector & $\begin{array}{c}\text { Efficiency Improvements of up to } 5 \% \text { in solar thermal collectors by utilizing nanofluids as an absorption } \\
\text { mechanism. }\end{array}$ & [44] \\
\hline $\begin{array}{l}\text { Dye sensitized } \\
\text { solar cell (DSSC) }\end{array}$ & $\begin{array}{l}\text { The (ISC) and (VOC) for cells operating with carbon and platinum coated counter electrodes were increased } \\
\text { from ( } 360 \text { to } 400 \mathrm{mV}) \text { and from }(175 \text { to } 200 \mu \mathrm{A}) \text {, respectively. }\end{array}$ & [45] \\
\hline $\begin{array}{l}\text { Power tower } \\
\text { solar collectors }\end{array}$ & Efficiency improvement on the order of $5-10 \%$ was possible with a nanofluid receiver. & [46] \\
\hline Solar PV cell & $\begin{array}{l}\text { Solar cell efficiency could be improved by increasing the absorption efficiency of light as well as the overall } \\
\text { radiation-to-electricity. }\end{array}$ & [47] \\
\hline $\begin{array}{l}\text { Direct-absorption } \\
\text { solar collectors }\end{array}$ & $\begin{array}{l}\text { The functionalized (CNS) nanofluids had the potential to effectively improve the solar absorption } \\
\text { capabilities of direct-absorption solar collectors. }\end{array}$ & [48] \\
\hline $\begin{array}{l}\text { Flat-plate solar } \\
\text { collector }\end{array}$ & $\begin{array}{l}\text { The thermal efficiency of solar collector was increased by about }(31.64 \%) \text { in comparison with the } \\
\text { conventional solar water heating system. }\end{array}$ & [49] \\
\hline $\begin{array}{l}\text { Building solar } \\
\text { heating system }\end{array}$ & $\begin{array}{l}\text { The effect of adding small quantities of nanoparticles }(\mathrm{MgO}) \text { to pure water minimized the heating loss time } \\
\text { while the heat gain was lower than pure water. }\end{array}$ & {$[50]$} \\
\hline $\begin{array}{l}\text { Solar water } \\
\text { heater }\end{array}$ & About $(10.88 \%)$ of an improved efficiency was observed at $(0.025 \%)$ volume fractions. & {$[51]$} \\
\hline $\begin{array}{l}\text { Solar water } \\
\text { heater }\end{array}$ & $\begin{array}{l}\text { The PCM was paraffin wax, and the nanocomposite was a paraffin wax base with } 1.0 \mathrm{wt} \% \text { additive of } 20 \text { - } \\
\mathrm{nm} \mathrm{Cu} \text { nanoparticles. The thermal conductivity of the nanocomposite was enhanced by } 24 \% \text { compared to the pure } \\
\text { paraffin wax. }\end{array}$ & [52] \\
\hline $\begin{array}{l}\text { Solar selective } \\
\text { absorbers }\end{array}$ & $\begin{array}{l}\text { A newly proposed solar selective absorbing with the composition of porous } \mathrm{C} / \mathrm{TiO} 2 \text { was successfully } \\
\text { prepared via UV irradiation polymerization- induced phase-separation method with the auxiliary of organic matter } \\
\text { PVP. The as-prepared spectrally selective absorption performance exhibits high solar absorbance. }\end{array}$ & [53] \\
\hline $\begin{array}{l}\text { PCM solar } \\
\text { thermal energy storage }\end{array}$ & $\begin{array}{l}\text { The nano } \mathrm{Cu} \text { addition to the paraffin wax contributed favourably where the melting and solidification } \\
\text { temperature of the nano } \mathrm{Cu}-\mathrm{PCM} \text { composite was reduced compared to the case of the pure paraffin wax. }\end{array}$ & [54] \\
\hline Solar energy & $\begin{array}{l}\text { The di-functional nanocomposite films with the ability to effectively and rapidly convert and store solar } \\
\text { energy as thermal energy. }\end{array}$ & {$[55]$} \\
\hline
\end{tabular}




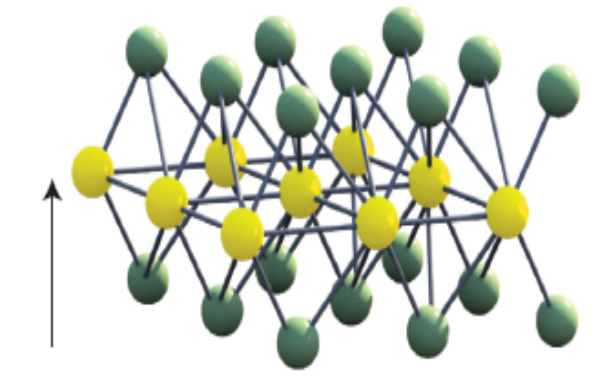

$0.7 \mathrm{~nm}$
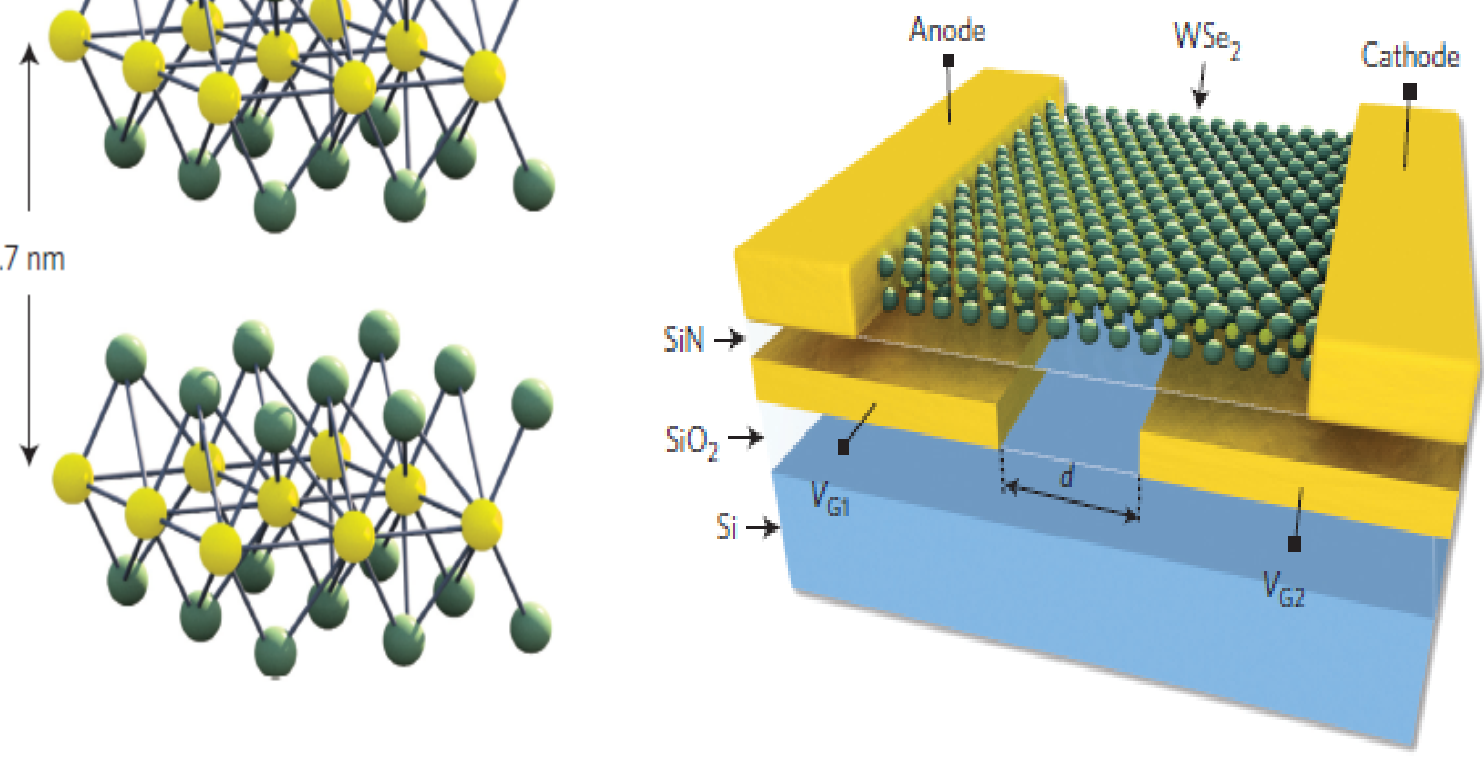

Figure 7. Three-dimensional schematic representation of atom in the cell ${ }^{[40]}$

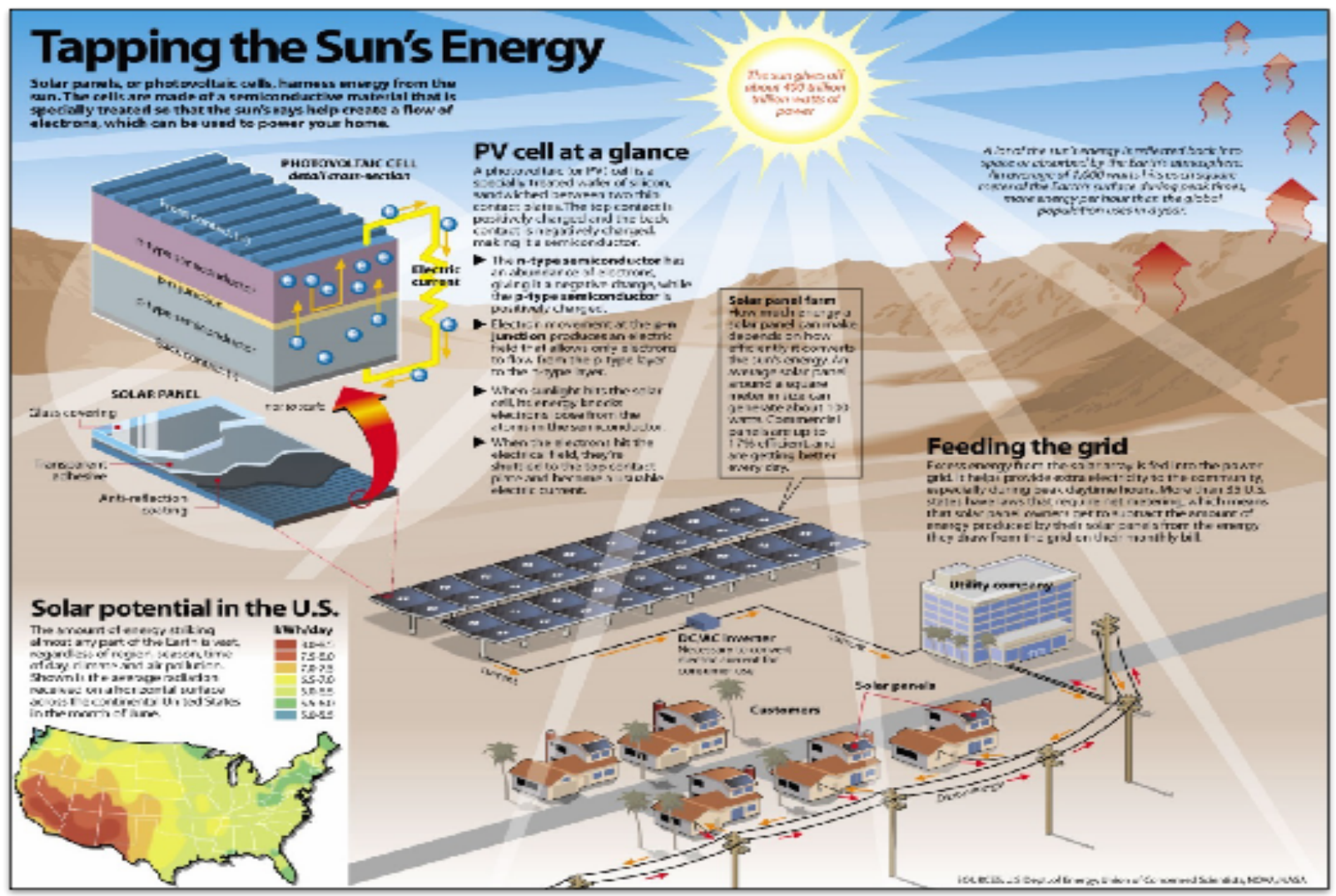

Figure 8. Higher efficiency can be concurrent by nanotechnology and its impact on the solar sector ${ }^{[42]}$ 


\subsection{Hydrogen energy}

Hydrogen energy conversion is divided into three different categories which includes I) diesel engines, II) Fuel cells and III) photocatalytic hydrogen production. Basically, electrochemical conversion and obtaining electricity by means of chemical reactions through a positively charged hydrogen ions $\mathrm{H}+$ with negatively charged oxygen $\mathrm{O}-$ ions and free electrons $\mathrm{e}-$ is one of the basics that hydrogen energy rely on in their functional working approach ${ }^{[56]}$. For example, the fuel cell has proven the high performance and also has a promising future. This important finding that made by William groove at $1938^{[57]}$ gave the chance for more research and development of this type as clean and sustainable resource of energy. Furthermore, the needs and challenges that occurred from other types give the priority to these types of energy resources to excel and widespread as shown in Figure 9.

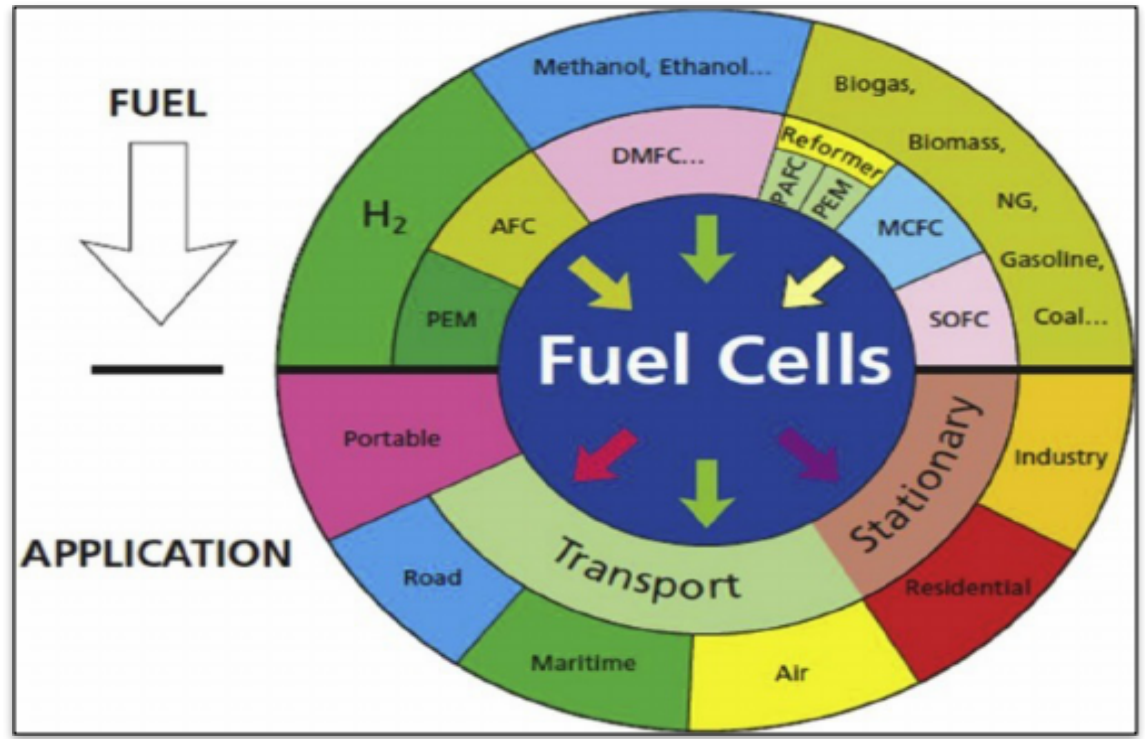

Figure 9. Fuel cell types and its various applications ${ }^{[58]}$

The utilization of nanotechnology in fuel cells has been triggered in a previous two decade. Although, Fuel cells research work has proven a highly and promising resource of energy since 1938 and even today in the extent of different temperatures. Yet, the need for performance improvement in terms of efficiency and design committed researchers to develop the structural levels (Conventional to Nano-scale). For example, different research work has been achieved in the development of fuel cell devices through the enhancement of used material and specifically the nano-scale levels ${ }^{[59-76]}$. In addition to, for nano-scale level the structure design ability to control the physical properties and accordingly will results in a superior performance achievement ${ }^{[77]}$. Various nanotechnological applications associated with Hydrogen energy can be observed from Table 2, which is highlighting the important finding with nanoscale utilization. 
Table 2. Some selected applications of nanotechnology in Hydrogen storage

\begin{tabular}{|c|c|c|}
\hline Application & Results and findings & Ref \\
\hline Diesel engine & The aluminium nanoparticles promoted the diesel fuel combustion. & [78] \\
\hline $\begin{array}{l}\text { Single-cylinder } \\
\text { diesel engine }\end{array}$ & $\begin{array}{l}\text { The total combustion heat increased while the concentration of smoke and nitrous oxide in the exhaust } \\
\text { emission from diesel engine was decreased when the diesel fuel mixed with aqueous aluminium nanofluid. }\end{array}$ & [79] \\
\hline Fuel cell & $\begin{array}{l}\text { The performance of the modified fuel cells was increased by using } \mathrm{TiO}_{2} / \mathrm{SnO}_{2} \text { nanoparticles especially at high } \\
\text { temperatures. }\end{array}$ & [80] \\
\hline $\begin{array}{r}\text { Photocatalytic } \\
\text { hydrogen production }\end{array}$ & $\begin{array}{l}\text { The photocatalytic hydrogen production offered unique opportunities to develop an alternative and } \\
\text { sustainable energy system and to reduce emission of greenhouse gases. }\end{array}$ & [81] \\
\hline $\begin{array}{l}\text { Hydrogen } \\
\text { production }\end{array}$ & $\mathrm{The} \mathrm{Ag} / \mathrm{TiO}_{2}$ nanocomposite films showed high stability for hydrogen production for more than one month. & [82] \\
\hline PEFCS & (CNTs) can be inserted into the components of fuel cells to improve its performance and reduce its cost. & [83] \\
\hline Fuel cell & $\begin{array}{l}\text { The prepared cobalt oxide/graphene nanocomposite had been used successfully for methanol oxidation as a } \\
\text { fuel cell application }\end{array}$ & [84] \\
\hline PEMFC & $\begin{array}{c}\text { The development of a hierarchical multi-scale paradigm promoted the convergence of nanotechnology to } \\
\text { sustainable energy technologies }\end{array}$ & [85] \\
\hline $\begin{array}{l}\text { Nanofluidic } \\
\text { fuel cell }\end{array}$ & Their nanofluidic fuel cell had a high overall efficiency, low-cost and miniaturized power sources & [86] \\
\hline $\begin{array}{l}\text { photocathode } \\
\text { for water splitting }\end{array}$ & $\begin{array}{l}\text { A high photocurrent density }\left(35 \mathrm{~mA} \mathrm{~cm}^{-2}\right) \text {, onset potential shift }(450 \mathrm{mV}) \text { and long-term stability were } \\
\text { achieved because of the single-crystalline nature of STO. }\end{array}$ & [87] \\
\hline $\begin{array}{l}\text { Fuel cell and } \\
\text { catalytic activities }\end{array}$ & $\begin{array}{l}\text { Both the magnitude and temporal profile of the observed oxygen uptake agree with an oxygen transport } \\
\text { mechanism described by 'remarkably mobile' oxygen defects. }\end{array}$ & [88] \\
\hline $\begin{array}{l}\text { PEMFC and } \\
\text { Li batteries }\end{array}$ & $\begin{array}{c}\text { The analysis showed that the challenge: the materials with the best potential environmental profiles during } \\
\text { the material extraction and production phase (less environmentally intensive materials, lower nanosynthesis energy } \\
\text { use and facile synthesis) }\end{array}$ & [62] \\
\hline $\begin{array}{l}\text { Fuel cells and } \\
\text { gas sensors }\end{array}$ & $\begin{array}{l}\text { Nanoporous atomically thin membranes have provided the fascinating opportunity to explore fundamental } \\
\text { questions in fluid flow at the smallest possible length scale. }\end{array}$ & [89] \\
\hline
\end{tabular}

\subsection{Biomass / Biofuels}

Another way that can provide energy through different routes includes thermal conversion, chemical conversion, biochemical conversion, and electrochemical conversion. The idea of this method basically classified into two major categories first and second generations as can be observed from the next block diagram in Figure 10.

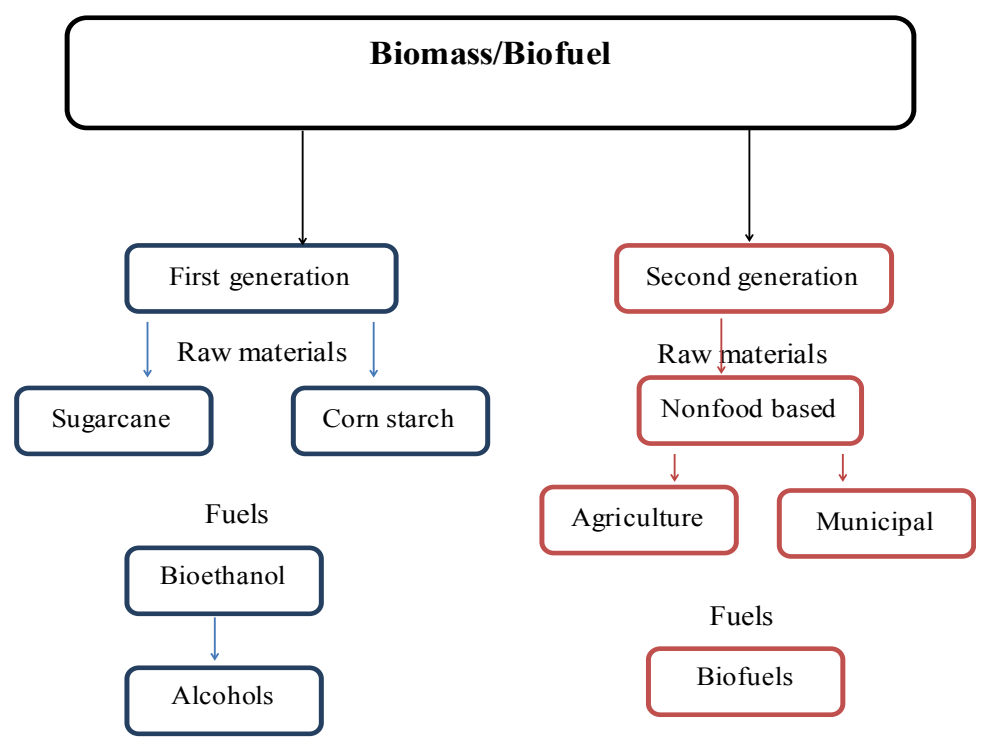

Figure 10. Block diagram of Biomass/biofuel categories 
Biomass is considered one of the renewable solutions in energy conversion ways, but still some challenges are concerned with this type. These challenges can be I) the formation of ash deposits and corrosion inside the boiler in the fuel combustion stage, II) NOx and SOx emissions from biomass burning power plants in addition to $\mathrm{CO}_{2}$ and Co and III) it can lead to rapid deactivation in the catalysts ${ }^{[89]}$. These mentioned problems can be overcome by nanotechnology usage through the materials resistance coating when manufacturing the combustion boilers ${ }^{[90,91]}$. The most essential and important applications of nanotechnology in Biofuels/Biomass can be observed from Table 3.

Table 3. Some selected applications of nanotechnology in Biofuels/Biomass

\begin{tabular}{|c|c|c|}
\hline Application & Results and findings & Ref \\
\hline Biofuels & $\begin{array}{l}\text { Theadditionofnanosizedceriumoxideparticlestobiodieselfuelwerefoundtoappreciably reduce the emission } \\
\text { levels of hydrocarbons and NOx components }\end{array}$ & [92] \\
\hline Biofuel & $\begin{array}{l}\text { The biodiesel yield reached up to } 96.8 \% \text { in the presence of } \mathrm{KF} / \mathrm{CaO} \text { nanocatalyst and could be used } \\
\text { efficiently to convert the oil with higher acid value into biodiesel. }\end{array}$ & [93] \\
\hline Biofuel & $\begin{array}{c}\text { They concluded that the nano-magnetic solid base catalyst used in the preparation of biodiesel gave a good } \\
\text { prospect of its development and application. }\end{array}$ & [94] \\
\hline Biofuel & The developed tandem-lipases system gave great potential for biodiesel production from waste grease. & [95] \\
\hline Biofuel & They obtained satisfactory yields and esterification ratio under optimal reaction conditions. & [96] \\
\hline Biofuel & They obtained a high biodiesel yield (97-100\%) with using (STNT) after a chemical reaction of $8 \mathrm{~h}$. & [97] \\
\hline Biofuel & $\begin{array}{c}\text { The catalyst played an important role in biodiesel production and using it to make the biodiesel production } \\
\text { more "greener" one. }\end{array}$ & [98] \\
\hline Biomass & $\begin{array}{l}\text { In the case of biomass, the results showed that the molecular traits of untreated and chemically processed } \\
\text { plant cell walls at the nanoscale that heretofore had remained elusive. }\end{array}$ & [99] \\
\hline Biofuel & $\begin{array}{l}\text { Synthesis of polymer-matrix nanocomposites with enhanced mechanical properties for structural } \\
\text { applications has led to only limited commercial success. This is due mainly to the inability to control the desired } \\
\text { microstructures in an economical or scalable way. }\end{array}$ & [100] \\
\hline Biomass & $\begin{array}{l}\text { Recent developments on catalyst design have yielded hydrophobic porous nanomaterials which displayed } \\
\text { very high catalytic activity for the conversion of carbohydrates to HMF together with greater efficiency of biphasic } \\
\text { systems. }\end{array}$ & [101] \\
\hline Biomass & $\begin{array}{l}\text { New integrated biorefinery process for the co-production of biofuels and silver nanomaterials. By } \\
\text { impregnating pure cellulose and corn stalk, a heterogeneous cellulosic biomass, with silver nitrate, followed by } \\
\text { pyrolysis, the yield of pyrolysis gases increased substantially, especially of hydrogen gas. }\end{array}$ & [102] \\
\hline
\end{tabular}

\subsection{Ocean and wind energy}

One of the greatest sources of clean and sustainable energy is wind and ocean tidal currents. For ocean tides, they are mainly resulted from the gravitational interaction of the moon and the sun ${ }^{[103]}$. Basically, the occurred friction between winds and water surface ${ }^{[104]}$ is the cause of ocean waves. The importance of this resource comes from their ability to store kinetic, thermal, chemical and biological energies ${ }^{[103,105,106]}$. Moreover, the ocean tidal power generation is naturally occurred along the ocean and sea. The output power that can be obtained in different region of the worlds, for example, USA around 2800 MW, UK 4200 MW, South Korea 1320 MW, Canada 5338 MW and the biggest one in India 7000 MW ${ }^{[103]}$. On the other hand, it is expected that by 2030 offshore turbine systems will be able to capture high wind speeds with efficient utility scale energy ${ }^{[107,108]}$.

The wind energy development will participate in the limiting of the expensive and inefficient on-site energy storage systems and will be able to match between the wind supply and demand ${ }^{[107]}$. The importance of Nanotechnology in both ocean tidal and wind energy can make a superior achievement in the energy supply and this what has been reported by Vivek Patel et al ${ }^{[109]}$ and Zhen Wen et al ${ }^{[110]}$ when they proposed and made a modification on wind turbine system through using composite materials with carbon based materials like nanotubes which has light weight and high strength in the rotor blade part. Also, for energy hybrid nanogenerator in the tidal system as it is clearly shown in Figure 11. Different ocean and wind energy applications can be observed from Table 4. 

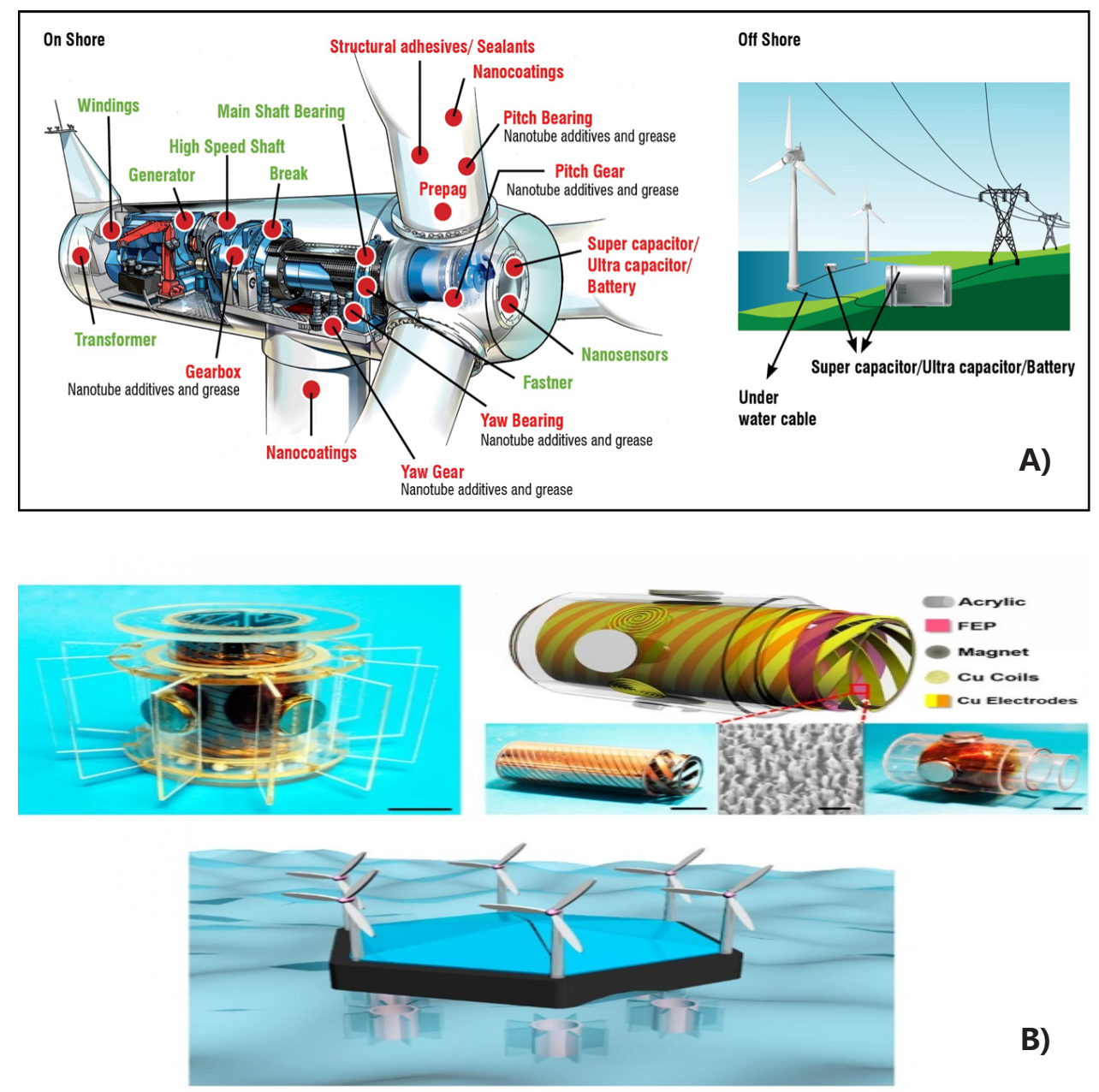

B)

Figure 11. nanotechnology utilization in a) onshore/offshore wind turbine and b) tidal nanogenerator system ${ }^{[109,110]}$

Table 4. Some selected applications of nanotechnology in wind and ocean energy

\begin{tabular}{c}
\hline Application \\
\hline Wind turbine gear box \\
$\begin{array}{c}\text { Nano-hydraulic } \\
\text { turbine. }\end{array}$ \\
Nano-sheets as a \\
lubricant additive in water \\
Nanogenerator for \\
wind energy harvesting \\
Nanogenerators for \\
harvesting wind energy
\end{tabular}

Nanostructured materials in the wind energy components

Results and findings
$\begin{gathered}\text { Nano-colloidal boron nitride additive in a commercial gear oil chemically reacted with the } \\ \text { borided surface to form a wear protective tribofilm. }\end{gathered}$

In the measurement of power output characteristics of a waterfall-type rotor without a plate, the maximum power coefficient CPmax $=0.58-0.66$ if the rotor is placed in an optimum position for the flow rate of the waterfall.

The h-BN nano-sheets, which can be simply and inexpensively dispersed, can be promising a "green" lubricant additive in water.

$$
\text { The proposed configuration doubled the frequency of the induced current and resulted in }
$$
an enhancement of the output power.

The triboelectrification based TENG farm is highlighted as being a little weight to be very cost effective, environmentally friendly, and effortlessly connected. Through the effective structural design, the introduced TENG farm converts the rotating motion into electricity. From the viewpoint of system arrangement, the TENG farm concept makes a start for a unique way in power generation for the triboelectrification-based large-scale green energy harvesting.

This technology offers blades reducedweightandincreaseddensityoverfirstgenerationca rbonnanotube-strengthenedglassfibre. In addition to the use of graphene in gearbox is able to remarkably reduce the wear rate and the coefficient of friction (COF) of steel parts. In the wind frames carbon nanotube-based cables are able to carry as much electric current as copper and are lighter. These have potential sustainability, durability and efficiency advantage.

Electromagnetic Hybrid Nanogenerator

Generate electricity under either rotation mode or fluctuation mode to collect energy from ocean tide, current, and wave due to the unique structure design. In this design, S-TENG can be fully isolated from the External environment through packaging and indirectly driven by the noncontact attractive forces between pairs of magnets, and then W-EMG can be easily hybridized. 


\subsection{Geothermal energy}

Geothermal energy has been used for a long time and it is considered one of the cleanest and renewable energy resources to practically indefinite supply. The estimation of this source makes it everlasting for a long time could be billions of years ${ }^{[116]}$. It is mainly depends on the heat coming from deep inside the earth's magma as seen in Figure 12.

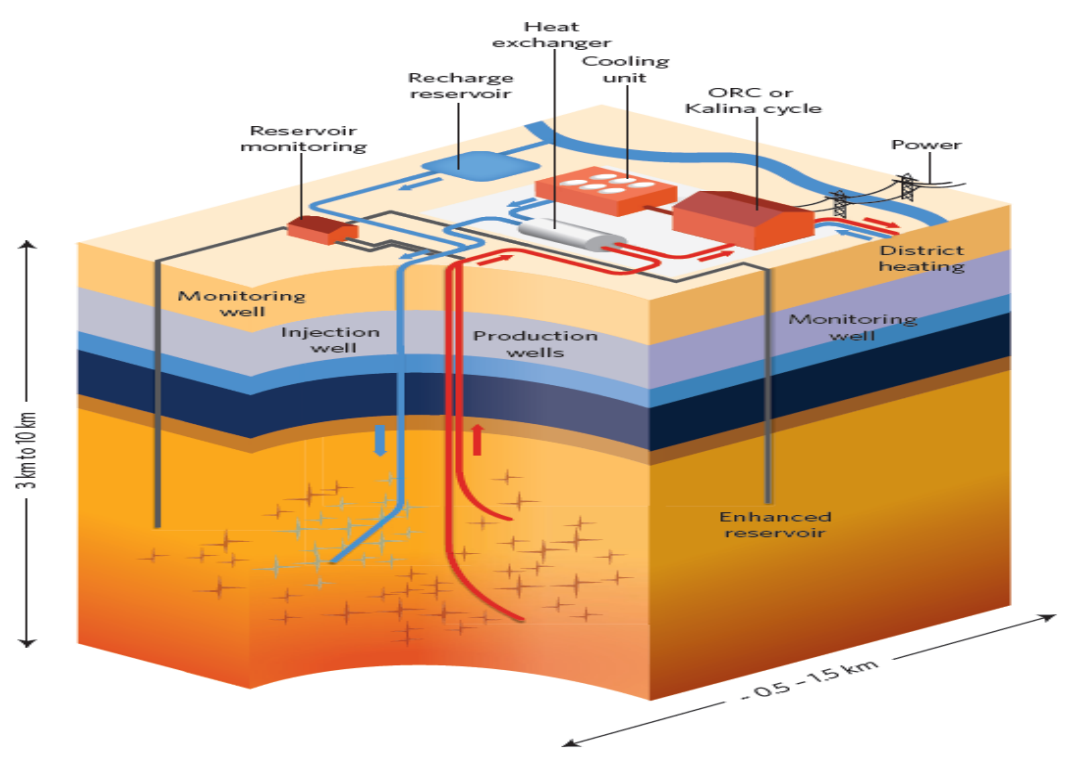

Figure 12. View of the geothermal system and possible enhancement ideas through fluid injection ${ }^{[120]}$

The benefits of this type of clean energy allow people to use in warming and producing electricity through well digging and underground heat pumping to the surface. There are many merits that geothermal can offer like low emission, free-combustion and sustainability. The limitation of geothermal energy is mainly the cost and hazards associated with deep drilling ${ }^{[117]}$. Nanotechnology is very helpful to overcome these challenges through improving the used material and introduce a nonstructural model that would be able to act as nano-storage particles with special liquid as alkanes, which are currently used to help turn power turbines in geothermal plants through evaporation. They are refining different liquid blends using the nanostructures, in hopes of potentially improving power production efficiency at geothermal plants by 30 to 40 percent. In geothermal power systems, this could help drive turbines with organic compounds at lower temperatures. Tests prove that technology is ready to be used within 5 years on existing geothermal systems ${ }^{[118,119]}$. Some selected applications of nanotechnology in geothermal energy are illustrated in Table 5.

Table 5. Some selected applications of nanotechnology in geothermal energy

\begin{tabular}{|c|c|c|}
\hline Application & Results and findings & Ref \\
\hline Geothermal power & $\begin{array}{l}\text { At that stage it was impossible to estimate the magnitude of the exploitable } \\
\text { resources of geothermal energy that lie hidden under our feet in the earth's crust. }\end{array}$ & [121] \\
\hline $\begin{array}{l}\text { Geothermal energy use in } \\
\text { Britain }\end{array}$ & $\begin{array}{l}\text { The economic viability of such a scheme would be enhanced by improving in deep } \\
\text { drilling methods, and allowed UK to use a huge power from a hot power underground }\end{array}$ & [122] \\
\hline Geothermal energy & $\begin{array}{l}\text { The used of deep drilling, however it is costly, but providing the world of } 0.25 \\
\text { from the total power, and it can be modified with minimum scale. }\end{array}$ & [123] \\
\hline Geothermal in China & $\begin{array}{l}\text { Enhancement of the obtained geothermal power by system modification through } \\
\text { the injection of some nanofluids. }\end{array}$ & [120] \\
\hline Geothermal power & $\begin{array}{l}\text { Nanofluids can encapsulate or absorb substantially higher orders of energy as } \\
\text { compared to the normal thermal fluids. }\end{array}$ & [124] \\
\hline $\begin{array}{l}\text { Supercritical geothermal } \\
\text { resources in the ductile } \\
\text { crust }\end{array}$ & $\begin{array}{l}\text { The fluid migration gives the potential exploitable supercritical geothermal } \\
\text { resources that may be more widespread than has been supposed. This easily can be done } \\
\text { through the control of rock permeability and nanofluid injection. }\end{array}$ & {$[125]$} \\
\hline
\end{tabular}




\section{Applications in energy storage}

Since the existence of electricity and huge consumption in various human needs, people were searching for an effective way to store that energy for frequent usage by direct and indirect ways (see Figure 13). Hence, the energy storage technology was initiated and effectively continued in achieving the requirements needed for the energy sector. The main purpose of energy storage for distributed generation applications is to be able to provide more plaint energy infrastructure with reasonable cost through different techniques including mechanical/ pneumatic systems, thermal systems, electrical systems, optical systems, magnetic systems and electrochemical systems ${ }^{[12]}$.

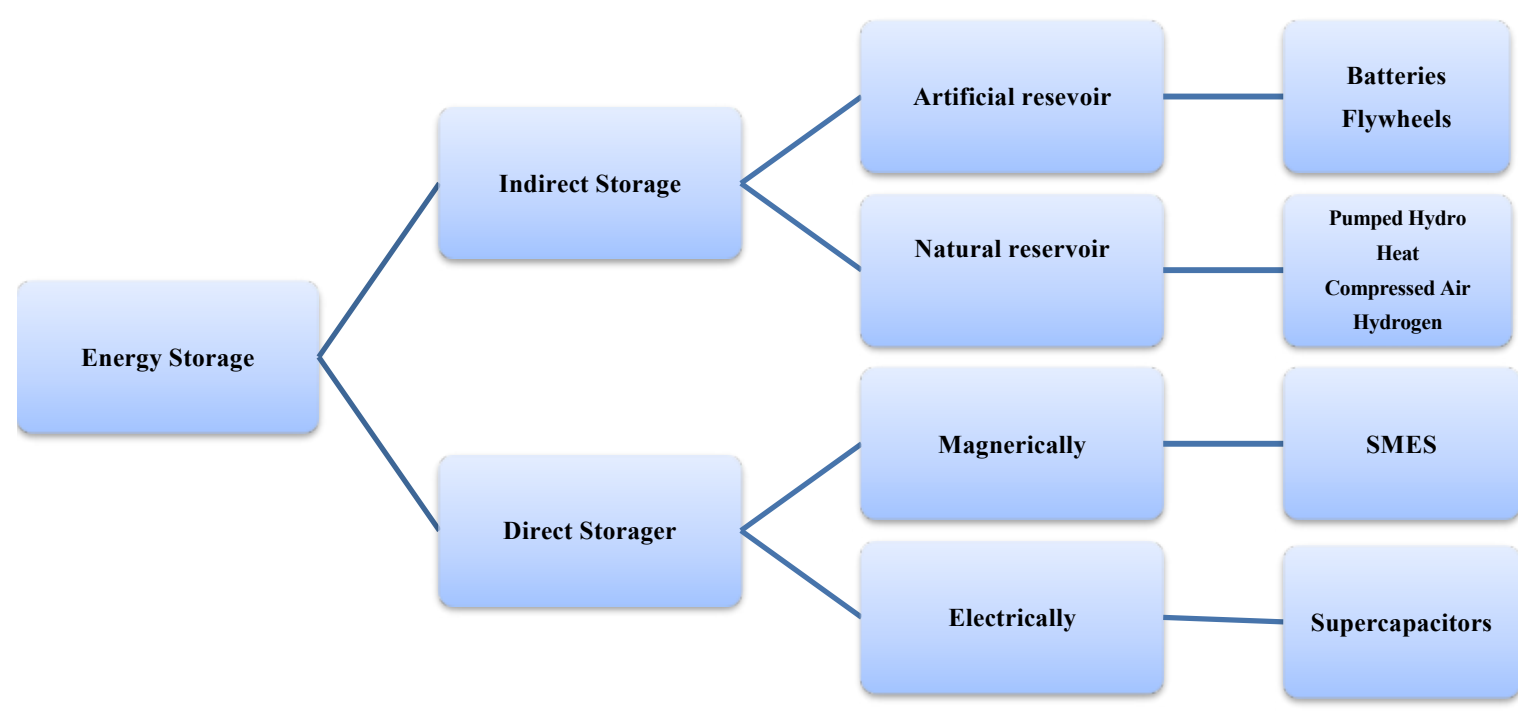

Figure 13. Energy storage strategy through direct and indirect methods ${ }^{[12]}$

In the previous two decades, many scientists directed their efforts to use the advantages of Nanoscience especially, in energy conversion and storage because of its vital role in confronting the challenges of serious environmental issues like global warming and the natural limitation of fossil fuels as well. The interesting findings offered by nanotechnology in energy devices were promising to overcome many challenges because of their unique properties in physical, chemical and mechanical state ${ }^{[126]}$. The coming subtopics are showing the application of nanotechnology in energy storage devices.

\subsection{Mechanical systems}

One of the main and important mechanical system types for the storage of energy are flywheels. It is very essential to consider the nanotechnology issues for these types as part of energy generation and storage. Few work was done under this subject and some trials were done to improve the efficiency and speed of flywheels by using Nano-material, Nano-fillers and Nano-composites in their rotors ${ }^{[127-129]}$.

\subsection{Thermal systems}

The importance of thermal energy storage as an inevitable component of fluctuant sustainable energy resources is mainly due to the efficiency and quality of versatile services. Time frame of the energy generation system in harvesting and saving energy with long and short-term is subjected to thermal energy storage within the height of its popularity. The world prediction of thermal energy storage marketing from 2015 to 2019 expected to reach US\$1,300 million or more in revenue ${ }^{[83-130]}$. Thereby, this type of energy can be stored with a wide range of temperatures using thermochemical and thermophysical energy processes. In thermal energy storage system, various thermal parameters, inherent design aspects and properties as well are depend in the utilized materials which essentially impacts on the systems efficiency ${ }^{[131]}$. Thus, to achieve fully required efficiency in the thermal storage, there are some factors must be considered such as I) Cooling/ heating profile of the system, II) Full or partial storage, III) Proper selection of storage materials IV) Active system or passive system, V) Power supply timeframe, VI) Heating/cooling plant redundancy, VII) Area /space existence and availability and VIII) Total consumed cost ${ }^{[132]}$. The impact of Nanoscience in energy field, especially in energy storage helped to enhance and achieve major factors needed in thermal energy storage after scientific principles met engineering endeavors. Therefore, nonexhaustive applications of Nanoscience and nanotechnology in the spectrum of energy and the 
environment can easily achieve. Also the nanostructured materials and grids are able to create an excellent thermophysical property change in bulk materials which results in an enhancement of their energy performance specifically in thermal energy systems ${ }^{[133]}$. This can be clearly observed from the study done by Khodadadi et al., when they succeeded to make phase change materials, PCM able to give highly thermal storage with the help of copper nano particles and allowed this to be suitable for thermophysical real-time energy storage applications ${ }^{[134]}$. However, the very huge merits, we can get into a thermal storage, but still some challenges exist like environmental impact depends on the waste treatment, agglomeration or aggregation of particles in PCMs can reduce their efficiency and the most important one is in human system cycle if nanomaterial enters it will have a serious adverse effect ${ }^{[133]}$.

\subsection{Optical systems}

The interesting of nanotechnology in studying light-matter interactions at the nanoscale gave the chance to store energy through optical systems ${ }^{[135-137]}$. Within the past three decades nano-optics have been investigated and with recent research work it has been drawn out to apply in a variety of areas. In energy storage it has shown promising results in the optical system. For instance, In chaotic energy harvesting which considered as one of the important storage mechanisms, by enabling the design of nanostructure in optical system allows high efficient energy harvesting within scale limit. The optimization of chaotic light scattering in chaotic cavities can be achieved by nanoparticles with asymmetric shapes, and the designed mechanism helps in absorbance in the visible range that behaves as dark-body ${ }^{[135]}$.

\subsection{Electrical systems}

Supercapacitor (supercap) is one of the efficient electrical systems that serve as an energy storage device with lower voltage limits ${ }^{[138]}$ with three main classifications I) Double layer capacitors, II) Pseudocapacitors and III) Hybrid capacitors. The usage of minimized scales microstructured and nanostructured have made revolutionary achievements in the energy storage devices ${ }^{[138-140]}$. Hence, using nanostructured carbon films in supercapsitors applications is very essential in achieving highly accessible surface area, high energy and high specific power compared to conventional batteries ${ }^{[141]}$. One of the most crucial needs in an energy storage device is to have a dense packing of active interfaces, this only can be obtained through the utilization of nano-porous structures of highly uniform carbon thin films. It allows also making well controlled array with regular nano-porous through self - assembly and using multilayer atomic layer deposition ${ }^{[142]}$ in capacitor components (see Figure 14) ${ }^{[143,144]}$.

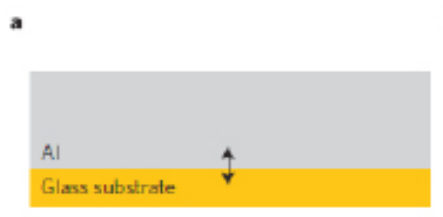

d
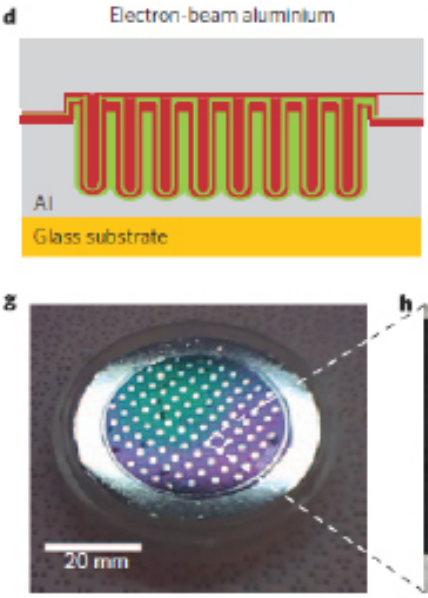

b
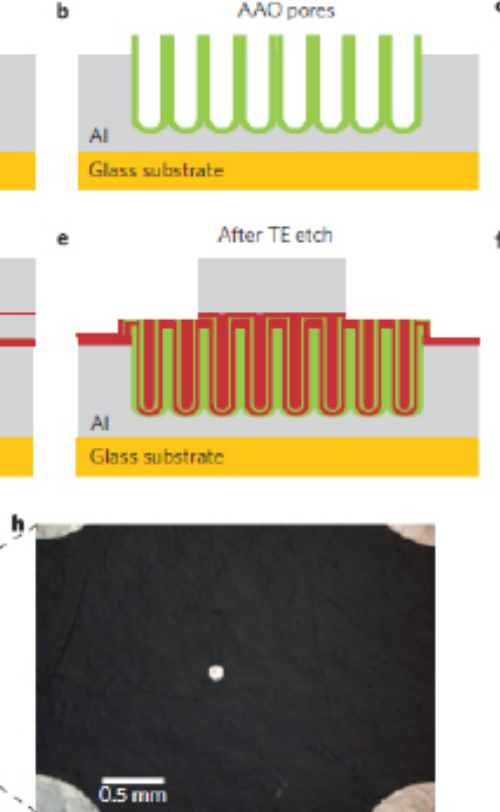

A)

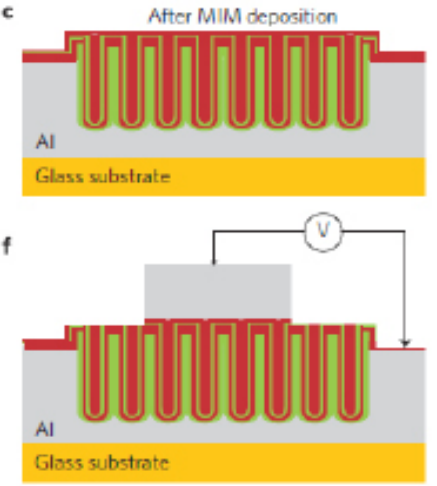

Glass substrate 

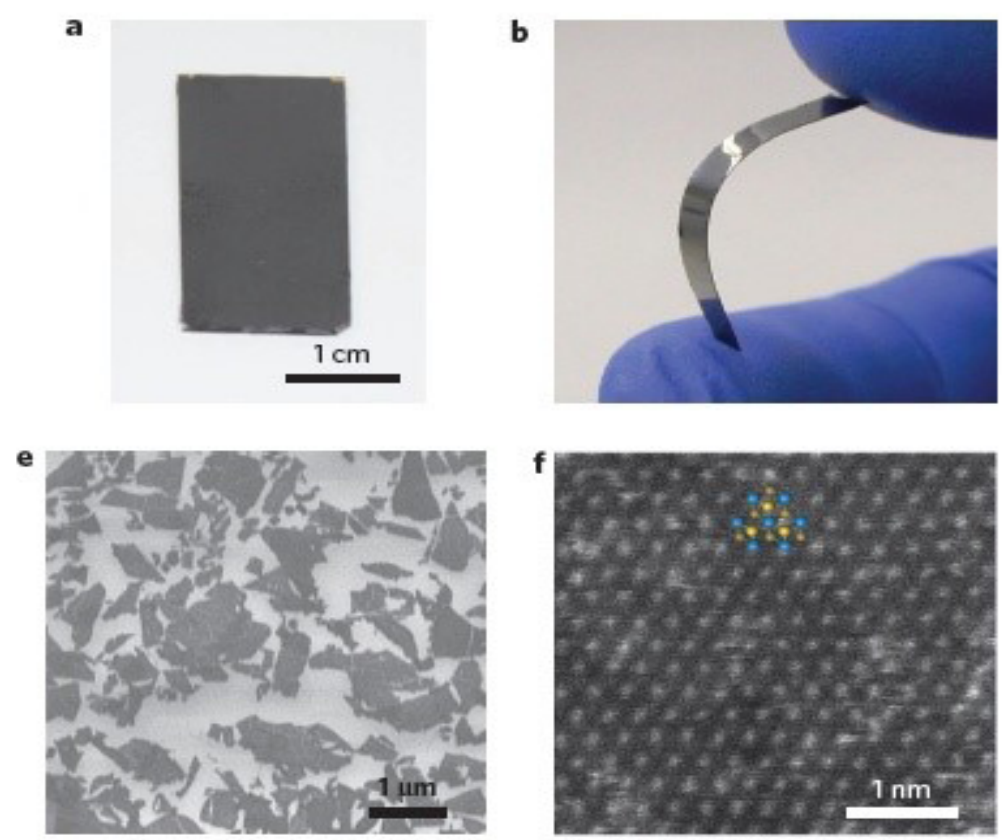

B)

Figure 14. Illustration of a) the process sequence to prepare nanostructured MIM capacitors and b) the metallic nanosheets as supercapacitor electrode materials ${ }^{[143,144]}$

The promising technology of Nanoscience in supercapacitors can be more beneficial when gives more interest to nanocarbon materials for their role in developing the devices for sustainable production energy storage ${ }^{[145]}$. Also using nanocarbons with chargeable batteries as Jun Liu ${ }^{[146]}$ discussed about implementation of graphene in energy storage devices and will allow to provide a specific capacity $>500 \mathrm{~mA} \mathrm{~h} \mathrm{~g}^{-1}$.

Another sort of the electrical systems can be found in batteries and especially ion-batteries ${ }^{[145-156]}$ which have some merits compared to other storage device types in the energy sector (as shown in Figure 15) like I) High energy density, II) Self-discharge, III) Neglecting of priming, IV) minimized maintenance and V) various types are available. There are some challenges are existing when batteries are used, for example, Ageing, Protection, and cost. But by the help of nanotechnology ${ }^{[157-168]}$ a superior achievement and enhancement can be obtained by scientists to increase the efficiency of these devices.

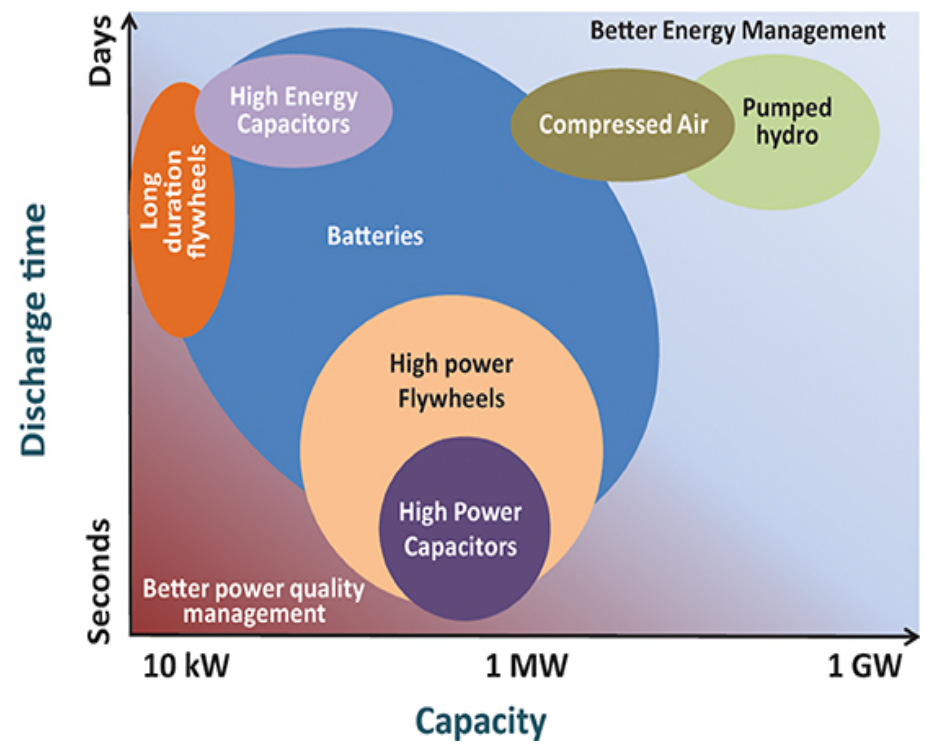

Figure 15. Energy storage technologies with system efficiency trend ${ }^{[169]}$ 
Nanostructered arrays in batteries allow overcoming the problems countered in Li metal batteries, as can be noticed from Figure16. The nanostructured arrays are able to control the volume shrinkage, electrode thermal stability well matched, highly controllable dense electrolyte and overcome the volume fluctuations. Therefore, good cyclability, thermal runaway handling and explosion hazards minimization could be easily achieved like the one used in lithium metal anodes Li- ions and bulk batteries ${ }^{[157,158]}$.
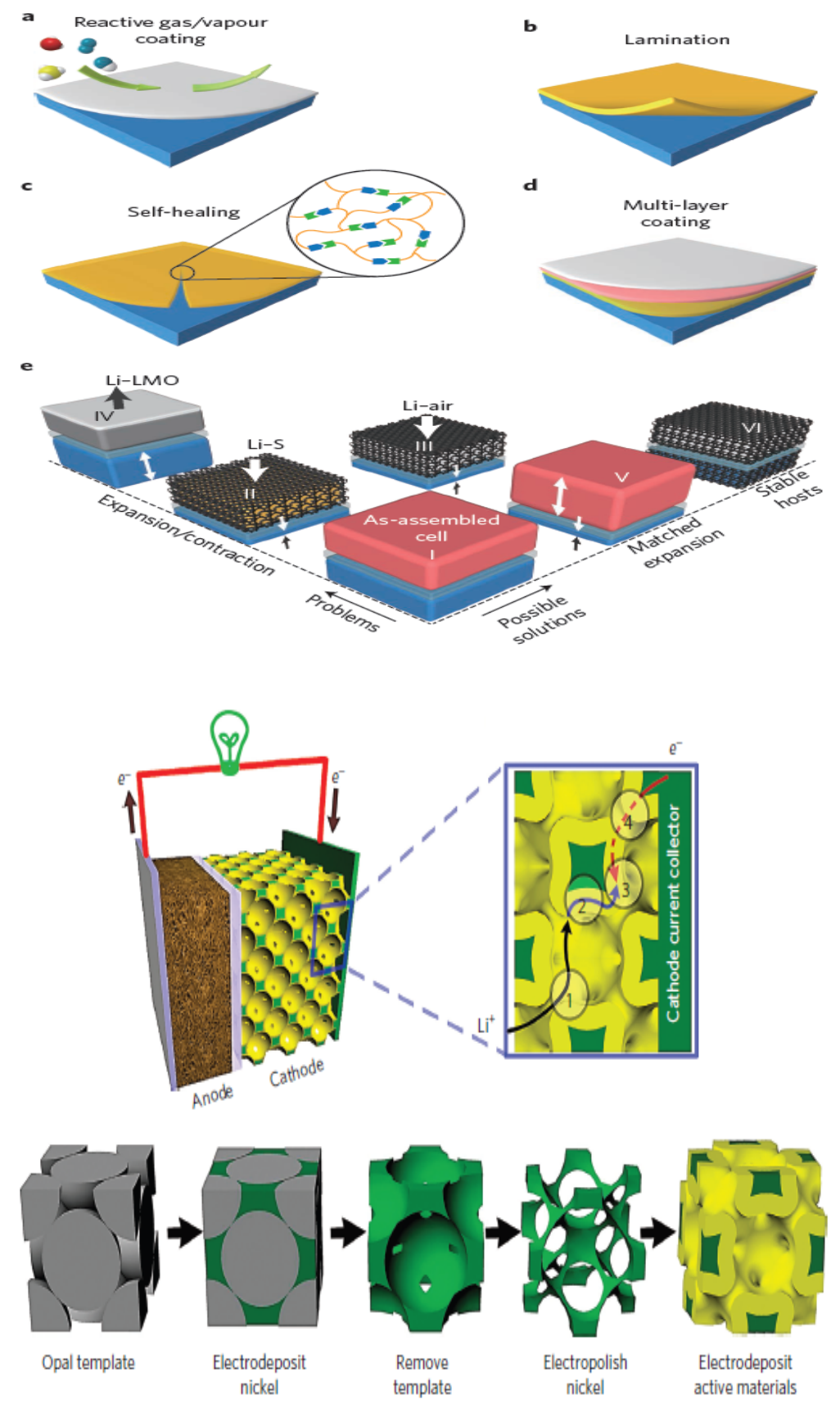

Figure 16. Nanostructure array manufacturing and working functions with bicontinuous battery electrode ${ }^{[157,158]}$ 


\section{Applications in energy efficiency}

The major problem in the energy sector is mainly focused on the lack and shortage of output power and efficiency in the long run. Hence, the developments of renewable energy resources are essential issues and have got the attention of researchers along the recent decades. Although, the term of energy efficiency became an interesting topic for more investigation, but very limited research work has been done on the development of techniques that improve the energy efficiency ${ }^{[170]}$. Recently essential attempts are made to increase the performance and the related efficiency of various resources of energy. The usage of nanotechnology in various devices mainly focus on applying new methods to reserve as much amount of energy as possible ${ }^{[15,171]}$.

The main concepts of these developments are relying on the design of utility energy efficiency schemes and the consideration of energy service (economics and cost) with main safety issues ${ }^{[172]}$. Thereby, applying these roles will increase the energy efficiency in the transport, industry and building sectors.

Basically, the application of nanotechnology will give a better chance to handle and control the performance and efficiency within very low temperature ranges. Hence, the main target of some studies to seek the traditional structures with green architecture developments (reducing power consumption) by the implementation of nanotechnology and its applications in this sector ${ }^{[15]}$. This can be achieved through nano-technological as Yanping Yuan et al. cited "[173] "surface treating (coating process) include anti-reflectivity, switchable transparency and darkening in photochromic glass, antifingerprint, fire protection, antibacterial, scratch-proofness, air cleaning, and microcapsules for fragrances".

The main target required from efficiency improvement is the current energy utilization and developing new energy sources. Hence, the need of nanotechnology may enhance the performance of many renewable/sustainable resources as well as enhance the performance of the conventional sources of energy like, the decrease of high emission of fossil fuel types attached with $\mathrm{CO}_{2}$ capture. Moreover, nanotechnology will allow and offer high surface area per unit volume that result in high activation in bulk materials. Also, chemical reaction mechanisms using nanotechnology will be speed up in addition to catalysis activity as well and as a result increase and enhance the efficiency of many processes ${ }^{[174]}$.

To improve the energy efficiency there must be a clear plan and strategy that offer reliable methods during various applications by means of different renewable resources of energy. This can be observed from the following Table $6^{[15]}$.

Table 6. Essential selected factors in energy efficiency considerations

\begin{tabular}{|c|c|c|c|c|}
\hline Factors & Strength & Weakness & Opportunities & Threat \\
\hline Energy Cost & * & & & \\
\hline Environmental issues control & $*$ & & & \\
\hline Sustainability & $*$ & & & \\
\hline Quality & $*$ & & & \\
\hline Income & & * & & \\
\hline Insulating techniques & & $*$ & & \\
\hline Skill\& experience & & $*$ & & \\
\hline Design and Maintenance & & $*$ & & \\
\hline \multicolumn{5}{|l|}{ Structure condition } \\
\hline Marketing & & & $*$ & \\
\hline Society economic influence & & & $*$ & \\
\hline Innovation and developments & & & $*$ & \\
\hline New specialization for Engineers & & & $*$ & \\
\hline Building or device Insurance costs & & & & $*$ \\
\hline Climate Hazardous & & & & $*$ \\
\hline Materials selection challenges & & & & * \\
\hline
\end{tabular}


The most important aspect in the structures or devices is now related to nanoarchitectures by selection and synthesis of low density, high porosity of nanoarchitectures that offer high surface area for chemical reactions with a persistent porous nanoarray for fast ionic and molecular outflow, like what is happening in hydrogen storage devices ${ }^{[15]}$ as shown in Figure 17.

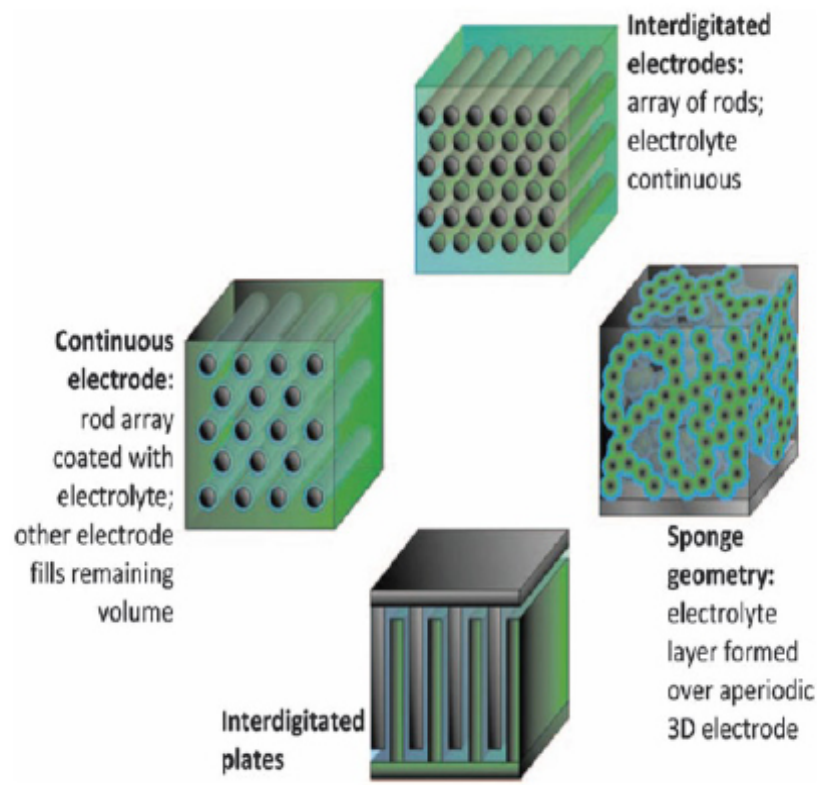

Figure 17. Geometrical design consideration of 3D batteries in energy-storing nanoarchitectures ${ }^{[171]}$

Another example can be presented through the performance of innovative nano-gel windows, when compared to conventional glazing systems, can be evaluated considering some important factors to be considered like I) Transmittance of lights (system diffuse), II) Thermal transmittance (heating and cooling loads) and III) Sound effects (reduction index) ${ }^{\text {[175] }}$.

Energy efficiency needs more developing and investigations, especially the ones related to climate and environments. Thereby, ensure the research and innovation quality is necessarily required across the different sectors with enhanced mobility of competence. The establishment of professional international network cooperation will activate and strength the energy efficiency programs with minimum loses in the whole world ${ }^{[176]}$. For examples, the initiation of nanotechnology projects in energy efficiency as an important element to satisfy the world's need will offer the best materials that can achieve the previous goals as mentioned in the previous section. Among these projects we can find this nanotechnology in batteries, fuel cells, aircrafts, building/ architectures and solar cells as shown in Figure 18. 


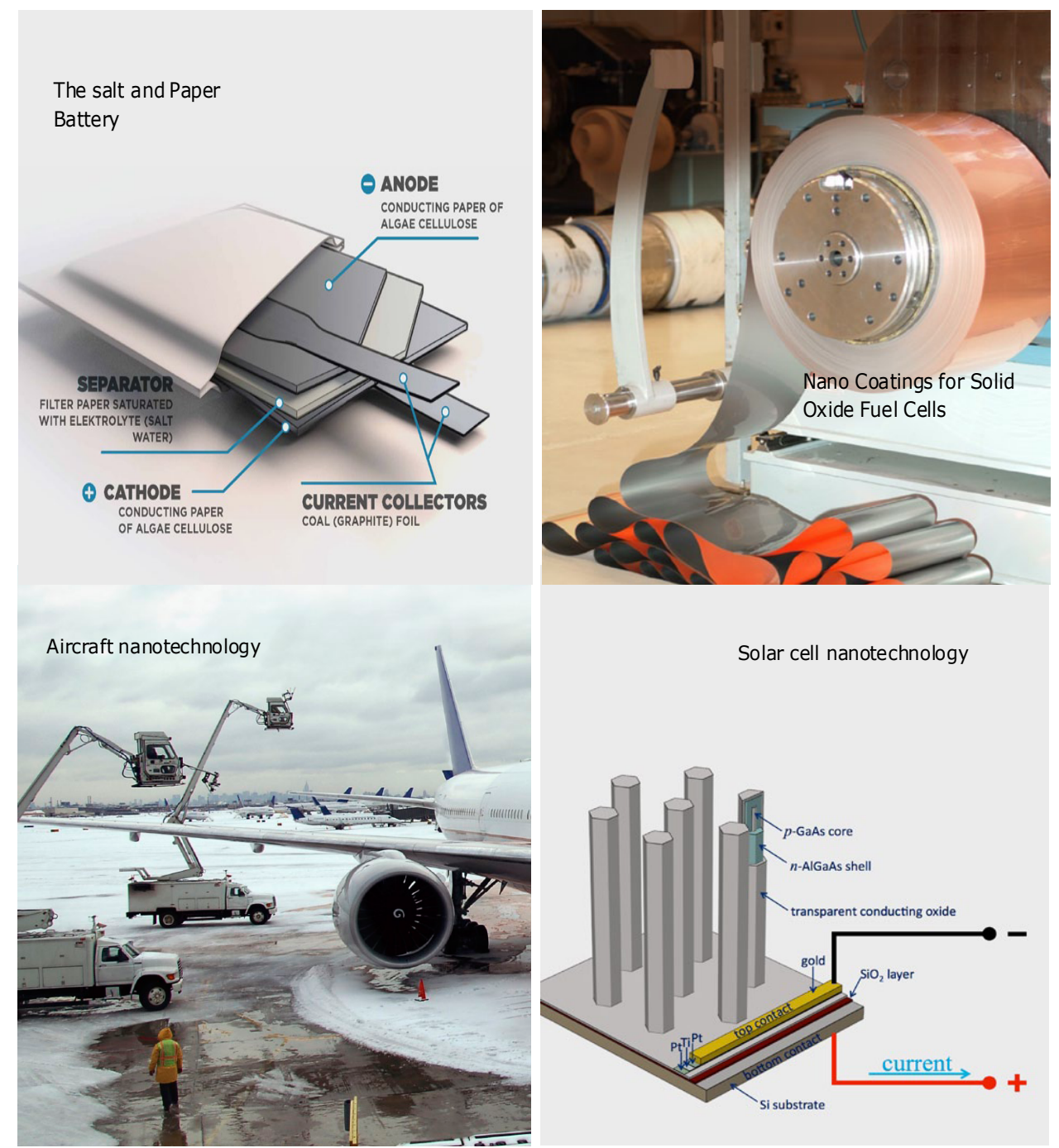

Figure18. Proposed projects from Nordic to carry out the research and development necessary for energy efficiency enhancement through utilization of nanotechnology ${ }^{1176]}$

\section{Conclusions}

The aim of this review work is mainly to spotlight the utilization of nanotechnology in main energy sectors (conversion, storage and efficiency) in recent years. The review focuses on a very essential part related to nanomaterial array manufacturing and processing as well. This review offers the most common and important applications that can show a superior performance after the application of nanotechnology than the conventional methods. Moreover, this work gives the direction that nanotechnology initiatives lead to better output in various energy sectors.

\section{Acknowledgements}

This work is a collaborative work between, Egypt, Bangladesh and Brunei the authors are very grateful to the collaborative authors and units for their support to finish this work .

\section{References}

[1] Hussein AK. Applications of nanotechnology in renewable energies - A comprehensive overview and understanding. Renew Sustain Energy Rev. 2015; 42: 4 60-76. doi: 10.1016/j.rser.2014.10.027.

[2] Scrosati B. Challenge of portable power. Nature. 1995; 373: 557-8. doi: 10.1038/373557a0.

[3] Zhang X, Cheng X, Zhang Q. Nanostructured energy materials for electrochemical energy conversion and storage: A 
review. J Energy Chem. 2016; 25: 967-84. doi: 10.1016/j.jechem.2016.11.003.

[4] Madakannan A, Munukutla L. AC 2007-2045: APPLICATION OF NANOTECHNOLOGY FOR ENERGY Application of Nano-technology for Energy Conversion and 2007.

[5] Kopsakangas-savolainen M. Energy Effeciency and Renewable Energy through Nano Technology. n.d.

[6] Subramani A, Badruzzaman M, Oppenheimer J, et al. Energy minimization strategies and renewable energy utilization for desalination: A review. Water Res. 2011; 45: 1907-20. doi: 10.1016/j.watres.2010.12.032.

[7] Tarascon JM, Armand M. Issues and challenges facing rechargeable lithium batteries. Nature. 2001; 414: 359-67. doi: $10.1038 / 35104644$.

[8] He J, Tritt TM. Thermal - Electrical Energy Conversion from the Nanotechnology Perspective. 2009.

[9] Sarkar J, Bhattacharyya S. Operating characteristics of transcritical CO2 heat pump for simultaneous water cooling and heating. Arch Thermodyn. 2012; 33: 23-40. doi: 10.1002/er.

[10] Summers CM. The Conversion of Energy. Sci Am. 1971; 225: 148-60. doi: 10.1038/scientificamerican0971-148.

[11] Kelvii Wei Guo. Green nanotechnology of trends in future energy: a review. Int. J. Energy Res. 2012; $36: 1-17$.

[12] San Martin JI, Zamora I, San Martín JJ, et al. Energy storage technologies for electric applications. Int Conf Renew Energies Power Qual. 2013; 1-6.

[13] Liu J, Kopold P, vanAken PA, et al. Energy Storage Materials from Nature through Nanotechnology: A Sustainable Route from Reed Plants to a Silicon Anode for Lithium-Ion Batteries. Angew Chemie - Int Ed. 2015; 54: 9632-6. doi:10.1002/anie.201503150.

[14] Materials NEW. and Energy Storage New Materials , Improved n.d.

[15] Donahoe FJ. Hierarchical Nanostructures for Energy Devices. J Franklin Inst. 2014; 271: $230-1$. doi:10.1039/9781849737500.

[16] Frs B, Nuzzo R, Rocha J, et al. Series Editors: Titles in the Series: How to obtain future titles on publication. n.d.

[17] $\mathrm{Hu}$ C, Song L, Zhang Z, et al. Tailored graphene systems for unconventional applications in energy conversion and storage devices. Energy Environ Sci. 2015; 8: 31-54. doi:10.1039/C4EE02594F.

[18] Timmerman D, Valenta J, Dohnalová K, et al. Step-like enhancement of luminescence quantum yield of silicon nanocrystals. Nat Nanotechnol. 2011; 6: 710-3. doi:10.1038/nnano.2011.167.

[19] Luther W. Application of Nano- technologies in the Energy Sector. WwwHessen-NanotechDe 2008:88.

[20] Baxter J, Bian Z, Chen G, et al. Nanoscale design to enable the revolution in renewable energy. Energy Environ Sci. 2009; 2: 559. doi:10.1039/b821698c.

[21] Shehzad K, Xu Y, Gao C, et al. Three-dimensional macro-structures of two-dimensional nanomaterials. Chem Soc Rev. 2016; 45: 5541-88. doi:10.1039/C6CS00218H.

[22] Wang ZL, Wu W. Nanotechnology-enabled energy harvesting for self-powered micro-/nanosystems. Angew Chemie Int Ed. 2012; 51: 11700-21. doi:10.1002/anie.201201656.

[23] Brinker CJ, Ginger D. N Anotechnology for S Ustainability: E Nergy C Onversion, S Torage, and C Onservation. Nanotechnology. 2012; 5: 361-7.

[24] Letcher TM, Scott JL. Materials for a Sustainable Future. 2012; 791. doi:10.1002/smll.201501300.

[25] Zuch M, Hgglund C, Chakarov D, Kasemo B. Nanoscience and nanotechnology for advanced energy systems. Curr Opin Solid State Mater Sci. 2006; 10: 132-43. doi:10.1016/j.cossms.2007.04.004.

[26] Markovic DS, Zivkovic D, Cvetkovic D, et al. Impact of nanotechnology advances in ICT on sustainability and energy efficiency. Renew Sustain Energy Rev. 2012; 16: 2966-72. doi:10.1016/j.rser.2012.02.018.

[27] Abdalla AM, Hossain S, Azad AT, et al. Nanomaterials for solid oxide fuel cells: A review. Renew Sustain Energy Rev 2018; 82: 353-68. doi:10.1016/j.rser.2017.09.046.

[28] Kamat PV, Flumiani M, Dawson A. Metal-metal and metal-semiconductor composite nanoclusters. Colloids Surf A Physiochem Eng Aspects. 2002; 202: 269-79.

[29] Smith Zachary Alden, Taylor, Katrina D. Renewable And Alternative Energy. ABC-CLIO. ISBN 978-1-59884-089-6. 2008. p. 174.

[30] Solar Energy. https://en.wikipedia.org/wiki/Solar_energy. [Accessed Augst 2019].

[31] Salvi BL, Subramanian KA, Panwar NL. Alternative fuels for transportation vehicles: A technical review. Renew Sustain Energy Rev. 2013; 25: 404-19. doi:10.1016/j.rser.2013.04.017.

[32] Morales M, Quintero J, Conejeros R, et al. Life cycle assessment of lignocellulosic bioethanol: Environmental impacts and energy balance. Renew Sustain Energy Rev. 2015; 42: 1349-61. doi:10.1016/j.rser.2014.10.097.

[33] Fan S. Photovoltaics: An alternative "Sun” for solar cells. Nat Nanotechnol. 2014; 9: 92-3. doi:10.1038/nnano.2014.9.

[34] Beard MC, Luther JM, Nozik AJ. The promise and challenge of nanostructured solar cells. Nat Nanotechnol. 2014; 9: 951-4. doi:10.1038/nnano.2014.292.

[35] Oh J, Yuan H-C, Branz HM. An 18.2\%-efficient black-silicon solar cell achieved through control of carrier recombination in nanostructures. Nat Nanotechnol. 2012; 7: 743-8. doi:10.1038/nnano.2012.166. 
[36] Sahaym U, Norton MG. Advances in the application of nanotechnology in enabling a "hydrogen economy." $J$ Mater Sci. 2008; 43: 5395-429. doi:10.1007/s10853-008-2749-0.

[37] K. Govardhan Reddy, T. G. Deepak, G. S. Anjusree, et al. On Global Energy Scenario, Dye-sensitized Solar Cells and the Promise of Nanotechnology. Optoelectron Adv Mater Rapid Commun. 2010; 4: 1166-9. doi:10.1039/b000000x.

[38] Samuel S. Mao y and XC, Lawrence. Selected nanotechnologies for renewable energy applicationsz. Int J Energy Res. 2007; 31: 619: 636. doi:10.1002/er.

[39] Abdin Z, Alim MA, Saidur R, et al. Solar energy harvesting with the application of nanotechnology. Renew Sustain Energy Rev. 2013; 26: 837-52. doi:10.1016/j.rser.2013.06.023.

[40] Pospischil A, Furchi MM, Mueller T. Solar-energy conversion and light emission in an atomic monolayer p-n diode. Nat Nanotechnol. 2014; 9: 257-61. doi:10.1038/nnano.2014.14.

[41] Mann SA, Oener SZ, Cavalli A, et al. Quantifying losses and thermodynamic limits in nanophotonic solar cells. Nat Nanotechnol. 2016; doi:10.1038/nnano.2016.162.

[42] Increasing Solar Efficiency by using nanotechnology application. https://webberenergyblog.wordpress. com/2013/05/05/increasing-solar-efficiency-by-using-nanotechnology-application/. [Accessed Augst 2019].

[43] Otanicar TP, Golden JS. Comparative Environmental and Economic Analysis of Conventional and Nanofluid Solar Hot Water Technologies. Environ Sci \&amp; Technol. 2009; 43: 6082-7.

[44] Otanicar TP, Carlson JD, Golden JS, et al. Impact of the Urban Heat Island on light duty vehicle emissions for the phoenix, AZ Area. Int J Sustain Transp. 2010; 4: 1-13. doi:10.1080/15568310802428552.

[45] Hossein Bazargan M. Performance of nano structured dye-sensitized solar cell utilizing natural sensitizer operated with platinum and carbon coated counter electrodes. Dig J Nanomater Biostructures. 2009; 4: 723-7.

[46] Taylor RA, Phelan PE, Otanicar TP, et al. Applicability of nanofluids in high flux solar collectors. $J$ Renew Sustain Energy. 2011; 3. doi:10.1063/1.3571565.

[47] Sethi VK, Pandey M, Shukla P. Use of Nanotechnology in Solar PV Cell. Int J Chem Eng Appl 2011; 2: 77-80. doi:10.7763/IJCEA.2011.V2.79.

[48] Jai Poinern G, Brundavanam S, Shah M, et al. Photothermal response of CVD synthesized carbon (nano)spheres /aqueous nanofluids for potential application indirect solar absorption collectors: a preliminary investigation. Nanotechnol Sci App l. 2012; 5: 49-59.

[49] Tiwari AK, Ghosh P, Sarkar J. Solar Water Heating Using Nanofluids - a Comprehensive Overview and Environmental Impact Analysis. Int J Emerg Technol Adv Eng. 2013; 3: 221-4.

[50] Obaid HN, Habeeb MA, Rashid FL, Hashim A. Thermal Energy Storage by Nanofluids. J Energy Technol Policy 2013; 3: 2224-3232.

[51] S. Bhagavathi Shankar, A. Manivannan. Performance Evaluation of Solar Water Heater Using Nanofluid. International Journal of Engineering Research and Applications (IJERA). 2013; 3(2): 793-798 793.

[52] Al-Kayiem HH, Lin SC. Performance evaluation of a solar water heater integrated with a PCM nanocomposite TES at various inclinations. Sol Energy. 2014; 109: 82-92. doi:10.1016/j.solener.2014.08.021.

[53] Cheng B, Wang KK, Wang KP, et al. Preparation and characterization of porous carbon-titania nanocomposite films as solar selective absorbers. $J$ Alloys Compd. 2015; 635: 129-35. doi:10.1016/j.jallcom.2015.02.069.

[54] Lin SC, Al-Kayiem HH. Evaluation of copper nanoparticles - Paraffin wax compositions for solar thermal energy storage. Sol Energy. 2016; 132: 267-78. doi:10.1016/j.solener.2016.03.004.

[55] Shang M, Zhang S, Li N, et al. Di-functional nanocomposite films for efficient conversion and storage of solar energy. Sol Energy Mater Sol Cells. 2017; 164: 188-92. doi:10.1016/j.solmat.2017.02.017.

[56] Varin RA, Czujko T, Wronski ZS. Nanomaterials for Solid State Hydrogen Storage Fuel Cells and Hydrogen Energy. 2009.

[57] Cook B. Introduction to fuel cells and hydrogen technology. Eng Sci Educ J. 2002; 11: 205.

[58] Setzler BP, Zhuang Z, Wittkopf JA, et al. Activity targets for nanostructured platinum-group-metal-free catalysts in hydroxide exchange membrane fuel cells. Nat Nanotechnol 2016; 11: 1020-5. doi:10.1038/nnano.2016.265.

[59] Hu Y, Zeng L, Minnich AJ, et al. Spectral mapping of thermal conductivity through nanoscale ballistic transport. Nat Nanotechnol. 2015; 10: 701-6. doi:10.1038/nnano.2015.109.

[60] Myung JH, Shin TH, Kim SD, et al. Optimization of Ni-zirconia based anode support for robust and high-performance 5 ?? $5 \mathrm{~cm} 2$ sized SOFC via tape-casting/co-firing technique and nano-structured anode. Int J Hydrogen Energy. 2015; 40: 2792-9. doi:10.1016/j.ijhydene.2014.12.077.

[61] Serrano E, Rus G, García-Martínez J. Nanotechnology for sustainable energy. Renew Sustain Energy Rev. 2009; 13: 2373-84. doi:10.1016/j.rser.2009.06.003.

[62] Ellingsen LA-W, Hung CR, Majeau-Bettez G, et al. Nanotechnology for environmentally sustainable electromobility. Nat Nanotechnol. 2016; 11: 1039-51. doi:10.1038/nnano.2016.237.

[63] Sholklapper TZ, Kurokawa H, Jacobson CP, et al. Nanostructured solid oxide fuel cell electrodes. Nanoletters. 2007; 7 : 
2136-41. doi:10.1021/n1071007i.

[64] Zhang H, Zhao F, Chen F, et al. Nano-structured Sm0.5Sr0.5CoO3 -?? electrodes for intermediate-temperature SOFCs with zirconia electrolytes. Solid State Ionics. 2011; 192: 591-4. doi:10.1016/j.ssi.2010.05.024.

[65] Zhu J, Zäch M. Nanostructured materials for photocatalytic hydrogen production. Curr Opin Colloid Interface Sci. 2009; 14: 260-9. doi:10.1016/j.cocis.2009.05.003.

[66] Structure C. Nanoscale Reaction Models in Solid Oxide Fuel Cells The challenge : Solution : 2010; $58: 4578$.

[67] Su PC, Prinz FB. Nanoscale membrane electrolyte array for solid oxide fuel cells. Electrochem Commun. 2012; 16: 77-9. doi:10.1016/j.elecom.2011.12.002.

[68] Zhou X, Singhal SC. Nanoscale Effects in Solid Oxide Fuel Cells. Types of Fuel Cells. 2000; 949: 99352.

[69] Kerman K, Lai BK, Ramanathan S. Nanoscale compositionally graded thin-film electrolyte membranes for lowtemperature solid oxide fuel cells. Adv Energy Mater. 2012; 2: 656-61. doi:10.1002/aenm.201100751.

[70] Jiang SP. Nanoscale and nano-structured electrodes of solid oxide fuel cells by infiltration: Advances and challenges. Int J Hydrogen Energy. 2012; 37: 449-70. doi:10.1016/j.ijhydene.2011.09.067.

[71] Li Q, Cao R, Cho J, et al. Nanocarbon electrocatalysts for oxygen reduction in alkaline media for advanced energy conversion and storage. Adv Energy Mater. 2014; 4. doi:10.1002/aenm.201301415.

[72] Cho GY, Lee YH, Cha SW. Multi-component nano-composite electrode for SOFCS via thin film technique. Renew Energy. 2014; 65: 130-6. doi:10.1016/j.renene.2013.07.044.

[73] Meng DD, Allen JS. Micro and Nanofluidics for Energy Conversion. IEEE Nanotechnol Mag. 2008; 2 : $19-23$. doi:10.1109/MNANO.2008.930952.

[74] Chockalingam R, Basu S. Impedance spectroscopy studies of Gd-CeO2-(LiNa)CO3 nano composite electrolytes for low temperature SOFC applications. Int J Hydrogen Energy. 2011; 36: 14977-83. doi:10.1016/j.ijhydene.2011.03.165.

[75] Lipomi DJ, Weiss EA, Whitesides GM. Green nanofabrication: Unconventional approaches for the conservative use of energy. Nanotechnol Energy Chall Second Ed. 2013; 355-405. doi:10.1002/9783527665105.ch13.

[76] Wang J. Barriers of scaling-up fuel cells: Cost, durability and reliability. Energy. 2015; 80: 509-21. doi:10.1016/ j.energy.2014.12.007.

[77] Kao M, Lin B, Tsung T. The study of high-temperature reaction responding to diesel engine performance and exhaust emission by mixing aluminum nanofluid in diesel fuel. In:18th internal combustion engine symposium. Jeju, Korea: 2005.

[78] Kao, M., Ting, C., Lin, B., et al. Aqueous Aluminum Nanofluid Combustion in Diesel Fuel. Journal of Testing and Evaluation. 2008; 36(2): 186-190.

[79] Abbaraju RR, Dasgupta N, Virkar A V. Composite Nafion Membranes Containing Nanosize TiO[sub 2]SnO[sub 2] for Proton Exchange Membrane Fuel Cells. J Electrochem Soc. 2008; 155: B1307. doi:10.1149/1.2994079.

[80] Tsuchiya M, Lai B-K, Ramanathan S. Scalable nanostructured membranes for solid-oxide fuel cells. Nat Nanotechnol. 2011; 6: 282-6. doi:10.1038/nnano.2011.43.

[81] M. Soylu, A. Dere, Abdullah G.Al-Sehemi, et al. Effect of calcination and carbon incorporation on NiO nanowires for photodiode performance open overlay panel. Microelectronic Engineering. 2018; 202: 51-59.

[82] Alenzi N, Liao WS, Cremer PS, et al. Photoelectrochemical hydrogen production from water/methanol decomposition using Ag/TiO2 nanocomposite thin films. Int J Hydrogen Energy. 2010; 35: 11768-75. doi:10.1016/ j.ijhydene.2010.08.020.

[83] Santanu Mukherjee, Alex Bates, Sang C. Lee, et al. A review of application of CNTs in PEM Fuel Cells. International Journal of Green Energy. 2015; 12(8).

[84] Elzatahry, A. A., Abdullah, A. M. El-Din, T. A. S. at al. Nanocomposite graphene-based material for fuel cell applications. International Journal of Electrochemical Science. 2012; 7(4): 3115-3126.

[85] Chung PS, So DS, Biegler LT, et al. Nanotechnology convergence and modeling paradigm of sustainable energy system using polymer electrolyte membrane fuel cell as a benchmark example. Nanotechnol Sustain Dev First Ed. 2014; 245-64. doi:10.1007/978-3-319-05041-6 20.

[86] Lee JW, Kjeang E. Nanofluidic fuel cell. J Power Sources. 2013; 242: 472-7. doi:10.1016/j.jpowsour.2013.05.129.

[87] Ji L, McDaniel MD, Wang S, et al. A silicon-based photocathode for water reduction with an epitaxial SrTiO3 protection layer and a nanostructured catalyst. Nat Nanotechnol. 2014; 10: 84-90. doi:10.1038/nnano.2014.277.

[88] Close T, Tulsyan G, Diaz CA, et al. Reversible oxygen scavenging at room temperature using electrochemically reduced titanium oxide nanotubes. Nat Nanotechnol. 2015; 10: 418-22. doi:10.1038/nnano.2015.51.

[89] Wang L, Boutilier MSH, Kidambi PR, et al, Hadjiconstantinou NG, Karnik R. Fundamental transport mechanisms, fabrication and potential applications of nanoporous atomically thin membranes. Nat Nanotechnol. 2017; 12: 509-22. doi:10.1038/nnano.2017.72.

[90] Steyn WJ. Potential Applications of Nanotechnology in Pavement Engineering. J Transp Eng. 2009; $135: 764-72$. doi:10.1061/(ASCE)0733-947X(2009)135:10(764). 
[91] Chen YX, Lavacchi A, Miller HA, et al. Nanotechnology makes biomass electrolysis more energy efficient than water electrolysis. Nat Commun. 2014; 5: 1-6. doi:10.1038/ncomms5036.

[92] Sajith V, Sobhan CB, Peterson GP. Experimental investigations on the effects of cerium oxide nanoparticle fuel additives on biodiesel. Adv Mech Eng. 2010; 2010. doi:10.1155/2010/581407.

[93] Wen L, Wang Y, Lu D, et al. Preparation of $\mathrm{KF} / \mathrm{CaO}$ nanocatalyst and its application in biodiesel production from Chinese tallow seed oil. Fuel. 2010; 89: 2267-71. doi:10.1016/j.fuel.2010.01.028.

[94] Hu S, Guan Y, Wang Y, et al. Nano-magnetic catalyst KF/CaO-Fe3O4 for biodiesel production. Appl Energy. 2011; 88: 2685-90. doi:10.1016/j.apenergy.2011.02.012.

[95] Yan J, Li A, Xu Y, et al. Efficient production of biodiesel from waste grease: One-pot esterification and transesterification with tandem lipases. Bioresour Technol. 2012; 123: 332-7. doi:10.1016/j.biortech.2012.07.103.

[96] Chen G, Guo CY, Qiao H, et al. Well-dispersed sulfated zirconia nanoparticles as high-efficiency catalysts for the synthesis of bis(indolyl)methanes and biodiesel. Catal Commun. 2013; 41: 70-4. doi:10.1016/j.catcom.2013.07.006.

[97] Hernández-Hipólito P, García-Castillejos M, Martínez-Klimova E, et al. Biodiesel production with nanotubular sodium titanate as a catalyst. Catal Today. 2014; 220-222: 4-11. doi:10.1016/j.cattod.2013.09.003.

[98] Konwar LJ, Boro J, Deka D. Review on latest developments in biodiesel production using carbon-based catalysts. Renew Sustain Energy Rev. 2014; 29: 546-64. doi:10.1016/j.rser.2013.09.003.

[99] Tetard L, Passian A, Farahi RH, et al. Opto-nanomechanical spectroscopic material characterization. Nat Nanotechnol. 2015; 10: 870-7. doi:10.1038/nnano.2015.168.

[100]Naskar AK, Keum JK, Boeman RG. Polymer matrix nanocomposites for automotive structural components. Nat Nanotechnol. 2016; 11: 1026-30. doi:10.1038/nnano.2016.262.

[101]Bhanja P, Bhaumik A. Porous nanomaterials as green catalyst for the conversion of biomass to bioenergy. Fuel.2016; 185: 432-41. doi:10.1016/j.fuel.2016.08.004.

[102]Xue J, Dou G, Ziade E, et al. Integrating sustainable biofuel and silver nanomaterial production for in situ upgrading of cellulosic biomass pyrolysis. Energy Convers Manag. 2017; 142: 143-52. doi:10.1016/j.enconman.2017.03.001.

[103]Khan N, Kalair A, Abas N, et al. Review of ocean tidal, wave and thermal energy technologies. Renew Sustain Energy Rev. 2017; 72: 590-604. doi:10.1016/j.rser.2017.01.079.

[104]Bennett VCC, Mulligan RP. Evaluation of surface wind fields for prediction of directional ocean wave spectra during Hurricane Sandy. Coast Eng. 2017; 125: 1-15. doi:10.1016/j.coastaleng.2017.04.003.

[105]Zheng CW, Li CY, Pan J, et al. An overview of global ocean wind energy resource evaluations. Renew Sustain Energy Rev. 2016; 53: 1240-51. doi:10.1016/j.rser.2015.09.063.

[106]Ashkenazy Y. Energy transfer of surface wind-induced currents to the deep ocean via resonance with the Coriolis force. J Mar Syst. 2017; 167: 93-104. doi:10.1016/j.jmarsys.2016.11.019.

[107]Qin C, Saunders G, Loth E. Offshore wind energy storage concept for cost-of-rated-power savings. Appl Energy. 2017; 201: 148-57. doi:10.1016/j.apenergy.2017.04.077.

[108]Carvalho D, Rocha A, Gómez-Gesteira M, et al. Offshore winds and wind energy production estimates derived from ASCAT, OSCAT, numerical weather prediction models and buoys - A comparative study for the Iberian Peninsula Atlantic coast. Renew Energy. 2017; 102: 433-44. doi:10.1016/j.renene.2016.10.063.

[109]Patel V, Mahajan YR. Techno-Commercial Opportunities of Nanotechnology in Wind Energy. Nanotechnol Energy Sustain. 2017; 1079-106. doi:10.1002/9783527696109.ch43.

[110]Wen Z, Guo H, Zi Y, et al. Harvesting Broad Frequency Band Blue Energy by a Triboelectric-Electromagnetic Hybrid Nanogenerator. ACS Nano. 2016; 10: 6526-34. doi:10.1021/acsnano.6b03293.

[111]Greco A, Mistry K, Sista V, et al. Friction and wear behaviour of boron based surface treatment and nano-particle lubricant additives for wind turbine gearbox applications. Wear. 2011; 271: 1754-60. doi:10.1016/j.wear.2010.11.060.

[112]Ikeda T, Iio S, Tatsuno K. Performance of nano-hydraulic turbine utilizing waterfalls. Renew Energy. 2010; 35: 293300. doi:10.1016/j.renene.2009.07.004.

[113]Cho DH, Kim JS, Kwon SH, et al. Evaluation of hexagonal boron nitride nano-sheets as a lubricant additive in water. Wear. 2013; 302: 981-6. doi:10.1016/j.wear.2012.12.059.

[114]Seol ML, Woo JH, Jeon SB, et al. Vertically stacked thin triboelectric nanogenerator for wind energy harvesting. Nano Energy. 2015; 14: 201-8. doi:10.1016/j.nanoen.2014.11.016.

[115]Ahmed A, Hassan I, Hedaya M, et al. Farms of triboelectric nanogenerators for harvesting wind energy: A potential approach towards green energy. Nano Energy. 2017; 36: 21-9. doi:10.1016/j.nanoen.2017.03.046.

[116]Sui D, Langåker VH, Yu Z. Investigation of Thermophysical Properties of Nanofluids for Application in Geothermal Energy. Energy Procedia. 2017; 105: 5055-60. doi:10.1016/j.egypro.2017.03.1021.

[117]Chen JR, Hong Q. Applications of Nanotechnology in Green Energy Manufacturing. Adv Mater Res. 2012; 442: 35-9. doi:10.4028/www.scientific.net/AMR.442.35.

[118]Sequeira S, Technologies M, Indicator D, et al. Applications of Nanotechnology in Renewable Energy Sources 
Exploitation Applications of Nanotechnology in Renewable Energy Sources Exploitation. 2015; doi:10.13140/ RG.2.1.1462.6008.

[119]Schulz R, Huot J, Liang G, et al. Recent developments in the applications of nanocrystalline materials to hydrogen technologies. Mater Sci Eng A Struct. 1999; 267: 240-5.

[120]Huang S. Geothermal energy in China. Nat Clim Chang. 2012; 2: 557-60. doi:10.1038/nclimate1598.

[121]Barnea J. Geothermal Power. 1971.

[122]May RM, Tapponnier, P., Molnar P. (C) 1976 Nature Publishing Group. Nature. 1976; 264: 319-24.

[123]Oxburgh ER. Geothermal Energy. Nature. 1980; 284: 380-1.

[124]Ganguly S, Kargupta K, Banerjee D. Nanotechnology and nanomaterials for new and sustainable energy engineering. In: Proceedings of the International Conference Nanomaterials: Applications and Properties; 2012; 1: 1-5.

[125]Watanabe N, Numakura T, Sakaguchi K, et al. Potentially exploitable supercritical geothermal resources in the ductile crust. Nat Geosci 2017; 10: 140-4. doi:10.1038/ngeo2879.

[126]Fisher R a., Watt MR, Jud Ready W, et al. Recent advances in polyaniline composites with metals, metalloids and nonmetals. Energy Environ Sci. 2013; 3: 4889-99. doi:10.1038/nmat1368.

[127]Testing Different Nanomaterials to Maximize Energy Storage in Flywheels By: Jacob Matriccino n.d.

[128]Boyle TJ, Lambert TN, Bell NS, et al. Nanofillers for Improved Flywheel Materials Project : Improved Flywheel Materials 2014.

[129]Sivonxav E, Boyle TJ, Lambert TN, et al. Improved Nanocomposite Materials for Flywheel Energy Storage Applications n.d.:87106.

[130]Safari A, Saidur R, Sulaiman FA, et al. A review on supercooling of Phase Change Materials in thermal energy storage systems. Renew Sustain Energy Rev. 2017; 70: 905-19. doi:10.1016/j.rser.2016.11.272.

[131]Mondragón R, Martínez-Cuenca R, Hernández L, et al. Nanotechnology and Nanomaterials for Thermal Energy Storage. Handb Clean Energy Syst. 2015; 1-13. doi:10.1002/9781118991978.hces224.

[132]Kalaiselvam S, Parameshwaran R. Chapter 10 - Thermal Energy Storage Systems Design. Therm Energy Storage Technol Sustain. 2014; 237-45. doi:http://dx.doi.org/10.1016/B978-0-12-417291-3.00010-4.

[133]Kalaiselvam S, Parameshwaran R. Chapter 8 - Nanotechnology in Thermal Energy Storage. Therm Energy Storage Technol Sustain. 2014; 163-202. doi:http://dx.doi.org/10.1016/B978-0-12-417291-3.00008-6.

[134]Khodadadi JM, Fan L, Babaei H. Thermal conductivity enhancement of nanostructure-based colloidal suspensions utilized as phase change materials for thermal energy storage: A review. Renew Sustain Energy Rev. 2013; 24: 418-44. doi:10.1016/j.rser.2013.03.031.

[135]Gu M, Li X, Cao Y. Optical storage arrays: a perspective for future big data storage. Light Sci Appl. 2014 ; 3: e177. doi:10.1038/lsa.2014.58.

[136]Sun Z, Liu G, Fu Z, et al. Nanostructured La2O3: Yb3+/Er3+: Temperature sensing, optical heating and bio-imaging application. Mater Res Bull. 2017; 92: 39-45. doi:10.1016/j.materresbull.2017.04.005.

[137]Nano-optics gets practical. Nat Nanotechnol. 2015; 10: 11-5. doi:10.1038/nnano.2014.314.

[138]Guerrero M, Romero E, Barrero F, et al. Supercapacitors: Alternative Energy Storage Systems. Prz Elektrotechniczny Electr Rev Page. 2009; 188-195.

[139]Kyeremateng NA, Brousse T, Pech D. Microsupercapacitors as miniaturized energy-storage components for on-chip electronics. Nat Nanotechnol. 2016; 12: 7-15. doi:10.1038/nnano.2016.196.

[140]Gao W, Singh N, Song L, et al. Direct laser writing of micro-supercapacitors on hydrated graphite oxide films. Nat Nanotechnol. 2011; 6: 496-500. doi:10.1038/nnano.2011.110.

[141]Diederich L, Barborini E, Piseri P, et al. Supercapacitors based on nanostructured carbon electrodes grown by clusterbeam deposition. Appl Phys Lett. 1999; 75: 2662-4. doi:10.1063/1.125111.

[142]Guan C, Wang J. Recent Development of Advanced Electrode Materials by Atomic Layer Deposition for Electrochemical Energy Storage. Adv Sci. 2016; 3: 1-23. doi:10.1002/advs.201500405.

[143]Banerjee P, Perez I, Henn-Lecordier L, et al. Nanotubular metal-insulator-metal capacitor arrays for energy storage. Nat Nanotechnol. 2009; 4: 292-6. doi:10.1038/nnano.2009.37.

[144]Acerce M, Voiry D, Chhowalla M. Metallic 1T phase MoS2 nanosheets as supercapacitor electrode materials. Nat Nanotechnol. 2015; 10: 313-8. doi:10.1038/nnano.2015.40.

[145]Su DS, Centi G. A perspective on carbon materials for future energy application. J Energy Chem. 2013; 22 : 151-73. doi:10.1016/S2095-4956(13)60022-4.

[146]Liu J. Charging graphene for energy. Nat Nanotechnol. 2014; 9: 739-41. doi:10.1038/nnano.2014.233.

[147]Guo Q, Sun Z, Gao M, et al. Porous V2O5-SnO2/CNTs composites as high performance cathode materials for lithium-ion batteries. J Energy Chem. 2013; 22: 347-55. doi:10.1016/S2095-4956(13)60043-1.

[148]Jamnik J, Maier J. Nanocrystallinity effects in lithium battery materials. Phys Chem Chem Phys. $2003 ; 5: 5215$. doi:10.1039/b309130a. 
[149]Liu Y, Ren L, Qi X, et al. Hydrothermal exfoliated molybdenum disulfide nanosheets as anode material for lithium ion batteries. J Energy Chem. 2014; 23: 207-12. doi:10.1016/S2095-4956(14)60137-6.

[150]Graetz J, Ahn CC, Yazami R, et al. Highly Reversible Lithium Storage in Nanostructured Silicon. Electrochem SolidState Lett. 2003; 6: A194. doi:10.1149/1.1596917.

[151]Bekaert E, Buannic L, Lassi U, et al. Electrolytes for Li- and Na-Ion Batteries: Concepts, Candidates, and the Role of Nanotechnology. Elsevier Inc. 2017; doi:10.1016/B978-0-323-42977-1.00001-7.

[152]Martin C. Driving change in the battery industry. Nat Nanotechnol. 2014; 9: 327-8. doi:10.1038/nnano.2014.92.

[153]Hu R, Sun W, Zeng M, et al. Dispersing SnO2 nanocrystals in amorphous carbon as a cyclic durable anode material for lithium ion batteries. J Energy Chem. 2014; 23: 338-45. doi:10.1016/S2095-4956(14)60156-X.

[154]Vlad A, Singh N, Galande C, et al. Design Considerations for Unconventional Electrochemical Energy Storage Architectures. Adv Energy Mater. 2015; 5: 1-53. doi:10.1002/aenm.201402115.

[155]Lee SW, Yabuuchi N, Gallant BM, et al. High-power lithium batteries from functionalized carbon-nanotube electrodes. Nat Nanotechnol. 2010; 5: 531-7. doi:10.1038/nnano.2010.116.

[156]Liu C, Gillette EI, Chen X, et al. An all-in-one nanopore battery array. Nat Nanotechnol. 2014; 9: 1031-9. doi:10.1038/nnano.2014.247.

[157]Zhang H, Yu X, Braun P V. Three-dimensional bicontinuous ultrafast-charge and -discharge bulk battery electrodes. Nat Nanotechnol. 2011; 6: 277-81. doi:10.1038/nnano.2011.38.

[158]Wu H, Chan G, Choi JW, et al. Stable cycling of double-walled silicon nanotube battery anodes through solidelectrolyte interphase control. Nat Nanotechnol. 2012; 7: 310-5. doi:10.1038/nnano.2012.35.

[159]Yu D, Goh K, Wang H, et al. Scalable synthesis of hierarchically structured carbon nanotube-graphene fibres for capacitive energy storage. Nat Nanotechnol. 2014; 9: 555-62. doi:10.1038/nnano.2014.93.

[160]Lin D, Liu Y, Cui Y. Reviving the lithium metal anode for high-energy batteries. Nat Nanotechnol. 2017; 12: 194206. doi:10.1038/nnano.2017.16.

[161]Fridman. Paper powers battery breakthrough Nanosynthesis by candlelight. Nat Nanotechnol. 2007 ; 2: 598-9. doi:10.1038/nnano.2007.318.

[162]Nazar LF, Goward G, Leroux F, et al. Nanostructured materials for energy storage. Int J Inorg Mater. 2001; 3: 191200. doi:10.1016/S1466-6049(01)00026-5.

[163]Tarascon J-M, Poizot P, Laruelle S, et al. Nano-sized transition-metal oxides as negative-electrode materials forlithium-ion batteries. Nature. 2000; 407: 496-9. doi:10.1038/35035045.

[164]Sides CR, Li NC, Patrissi CJ, et al. Nanoscale materials for lithium-ion batteries. Mrs Bull. 2002; 27 : 604-7. doi:10.1557/mrs2002.195.

[165]Croce F, Appetecchi GB, Persi L, et al. Nanocomposite polymer electrolytes for lithium batteries. Nature. 1998; 394: 456-8. doi:10.1038/28818.

[166]Wen L, Xu R, Mi Y, et al. Multiple nanostructures based on anodized aluminium oxide templates. Nat Nanotechnol. 2016; 12: 244-50. doi:10.1038/nnano.2016.257.

[167]Zheng G, Lee SW, Liang Z, et al. Interconnected hollow carbon nanospheres for stable lithium metal anodes. Nat Nanotechnol. 2014; 9: 618-23. doi:10.1038/nnano.2014.152.

[168]Braun P V, Nuzzo RG. Batteries: Knowing when small is better. Nat Nanotechnol. 2014; 9: 1-2. doi:10.1038/ nnano.2014.263.

[169]Badwal SPS, Giddey SS, Munnings C, et al. Emerging electrochemical energy conversion and storage technologies. Front Chem. 2014; 2: 1-28. doi:10.3389/fchem.2014.00079.

[170]Cui Q, Li Y. An empirical study on energy efficiency improving capacity: the case of fifteen countries. Energy Effic. 2015; 8: 1049-62. doi:10.1007/s12053-015-9337-3.

[171]Türkoğlu S. P., Kardoğan P. S. Ö. The Role and Importance of Energy Efficiency for Sustainable Development of the Countries. In: Firat S., Kinuthia J., Abu-Tair A. (eds) Proceedings of 3rd International Sustainable Buildings Symposium (ISBS 2017). ISBS 2017. Lecture Notes in Civil Engineering, vol 7. Cham: Springer; 2018.

[172]Waide P, Buchner B. Utility energy efficiency schemes: Savings obligations and trading. Energy Effic. 2008; 1: 297311. doi:10.1007/s12053-008-9024-8.

[173]Yuan Y, Yu X, Yang X, et al. Bionic building energy efficiency and bionic green architecture: A review. Renew Sustain Energy Rev. 2017; 74: 771-87. doi:10.1016/j.rser.2017.03.004.

[174]Tegart G. Energy and nanotechnologies: Priority areas for Australia's future. Technol Forecast Soc Change. 2009; 76: 1240-6. doi:10.1016/j.techfore.2009.06.010.

[175]Buratti C, Moretti E. Silica nanogel for energy-efficient windows. Nanotechnol Eco-Efficient Constr. 2013; 207-35. doi:10.1533/9780857098832.2.207.

[176]Energy Efficiency with Nanotechnology 2010. 